OPEN ACCESS

Edited by:

Kate Stringaris,

National Institutes of Health (NIH).

United States

Reviewed by:

Robert J. Canter,

University of California, Davis,

United States

Amorette Barber,

Longwood University, United States

*Correspondence:

Dongsheng Huang

dshuang@zju.edu.cn

Yibing Xu

yibingxu@zju.edu.cn

tThese authors have contributed equally to this work

Specialty section:

This article was submitted to

Cancer Immunity and Immunotherapy,

a section of the journal

Frontiers in Immunology

Received: 17 January 2019 Accepted: 13 May 2019

Published: 31 May 2019

Citation:

Hu W, Wang G, Huang D, Sui M and Xu Y (2019) Cancer Immunotherapy

Based on Natural Killer Cells: Current

Progress and New Opportunities.

Front. Immunol. 10:1205.

doi: 10.3389/fimmu.2019.01205

\section{Cancer Immunotherapy Based on Natural Killer Cells: Current Progress and New Opportunities}

\author{
Weilei $\mathrm{Hu}^{1 \dagger}$, Guosheng Wang ${ }^{1 \dagger}$, Dongsheng Huang ${ }^{2,3 *}$, Meihua Sui ${ }^{2,3}$ and Yibing $\mathrm{Xu}^{1 *}$ \\ ${ }^{1}$ Institute of Translational Medicine, Zhejiang University School of Medicine, Hangzhou, China, ${ }^{2}$ Department of Surgery \& \\ Clinical Research Institute of Zhejiang Provincial People's Hospital, People's Hospital of Hangzhou Medical College, \\ Hangzhou, China, ${ }^{3}$ Center for Cancer Biology and Innovative Therapeutics, Key Laboratory of Tumor Molecular Diagnosis \\ and Individualized Medicine of Zhejiang Province, Hangzhou, China
}

Cancer immunotherapy has been firmly established as a new milestone for cancer therapy, with the development of multiple immune cells as therapeutic tools. Natural killer (NK) cells are innate immune cells endowed with potent cytolytic activity against tumors, and meanwhile act as regulatory cells for the immune system. The efficacy of NK cell-mediated immunotherapy can be enhanced by immune stimulants such as cytokines and antibodies, and adoptive transfer of activated NK cells expanded ex vivo. In addition, NK cells can arm themselves with chimeric antigen receptors (CARs), which may greatly enhance their anti-tumor activity. Most recently, extracellular vesicles (EVs) derived from NK cells show promising anti-tumor effects in preclinical studies. Herein, we carefully review the current progress in these NK cell-based immunotherapeutic strategies (NK cells combined with stimulants, adoptive transfer of NK cells, CAR-NK cells, and NK EVs) for the treatment of cancers, and discussed the challenges and opportunities for opening a new horizon for cancer immunotherapy.

\footnotetext{
Keywords: cancer immunotherapy, natural killer cell, cytokines, antibodies, adoptive cellular immunotherapy, chimeric antigen receptor, extracellular vesicles
}

\section{INTRODUCTION}

Cancer immunotherapy, which works by activating the body's own immune system, has become an increasingly important treatment option for cancers. In recent years, successes in anti-tumor treatments with antibodies and cell-based immunotherapy has become landmark events in the history of tumor treatment $(1,2)$. As innate immune cells, natural killer (NK) cells are unique and play pivotal functions in cancer immune surveillance. NK cells can eliminate a variety of abnormal or stressed cells without prior sensitization, and even preferentially kill stem-like cells or cancer stem cells (3-5). Upon forming immune synapses with target cells, NK cells release preformed cytolytic granules, including perforin, and granzymes, of which function is to induce cell lysis. Several studies have successfully exploited adoptive transfer of NK cells against various tumors, especially hematological malignancies.

However, cancers employ various tactics to delay, alter, or even stop anti-tumor immunity, leading to failures in the control of tumor growth. The anti-tumor response of NK cells also faces a lot of limitations. First, the poor ability of NK cells to reach tumor tissues limits their application as therapies for solid tumors. This is a common problem of cellular immunotherapy strategies (6). 
Second, changes in NK cell-activating receptors and their ligands in tumors, may lead to a decreased therapeutic response and tumor progression (7). For example, high levels of NKG2D (Natural-killer Group 2, Member D) ligands are detected in the early stages of colorectal cancer, but their expression decreases as the disease progresses (8). Third, the tumor microenvironment (TME) remains a major barrier to the effectiveness of adoptively transferred NK cells. For example, tumor-infiltrating immune cells such as dendritic cells (DCs), suppressive or tolerogenic macrophages and regulatory $\mathrm{T}$ (Treg) cells as well as cancerassociated fibroblasts, which are embedded in the extracellular matrix, may meddle in NK cell activation either through secretion of immunosuppressive cytokines or by interfering with receptor expression $(9,10)$. For instance, in TEM, TGF- $\beta$ is recognized as a main inhibitory cytokine of NK cells which limits the number and anti-metastatic function of NK cells. Other factors, such as prostaglandin E2, adenosine or indoleamine 2,3dioxygenase, can also block the cytotoxic activity of NK cells by, respectively, inducing myeloid-derived supressor cells (11), binding to adenosine A2A receptors expressed on NK cells (12) or catalyzing tryptophan-producing L-kynurenine to inhibit the expression of NKp46 and NKG2D on NK cells $(7,13)$. In addition, the cytotoxicity of NK cell was found to be inhibited by activated-platelets in the malignant milieu via a series of mechanisms, including the shed and transfer of their MHC class I molecules to tumor cells; undermining NK cell effector function via platelet-derived TGF- $\beta$ (14) or shielding tumor cells from NK cell attack (15-17).

In order to overcome the above problems many strategies have been explored, either by adding immune stimulants to produce synergistic effects, adoptive transfer of NK cells expanded in vitro, or by genetically modifying NK cells themselves to be stronger and more resilient. In addition, nano-vesicle structures secreted by NK cells known as extracellular vesicles (EVs) come into the spotlight for their applications in cancer therapies.

\footnotetext{
Abbreviations: NK, Natural killer; CARs, Chimeric antigen receptors; EVs, extracellular vesicles; NKG2D, Natural-killer Group 2, Member D; TME, Tumor microenvironment; DCs, Dendritic cells; Treg, Regulatory T; TGF$\beta$, Transforming growth factor- $\beta$; BM, Bone marrow; PB, Peripheral blood; IFN $\gamma$, Interferon gamma; KIR, Killer-immunoglobulin-like receptors; CTLA-4, Cytotoxic T-lymphocyte-associated protein 4; PD-1, Programmed death-1; Ig, Immunoglobulin; TIGIT, T cell immunoreceptor with Ig and ITIM domains; TIM-3, T cell Ig and mucin domain containing-3; DNAM-1, DNAX Accessory Molecule-1; DR, Death receptor; ADCC, Antibody-dependent cell-mediated cytotoxicity; IgG, Immunoglobulin G; TAA, Tumor-associated antigen; MHC, Major histocompatibility complex; IL, Interleukin; APC, Antigen receptor cell; rh, recombinant human; MTD, maximum tolerated dose; allo-HCT, allogeneic hematopoietic cell transplantation; DLT, dose-limiting toxicities; GVHD, Graftvs.-host disease; BCG, Bacillus Calmette Guerin; AML, Acute myeloid leukemia; EBV, Epstein-Barr virus; mAb, Monoclonal antibody; CDC, Complementdependent cytotoxicity; MICA, Major Histocompatibility Complex Class-I chain related gene A; MICB, Major Histocompatibility Complex Class-I chain related gene B; BiKE, Bispecific killer engager; TriKE, trispecific killer engager; $\mathrm{ScFv}$, Single chain antibody fragment; MM, Multiple myeloma; LAG-3, Lymphocyteactivation gene 3; aAPCs, Artificial antigen-presenting cells; FDA, Food and Drug Administration; PBMC, Peripheral blood mononuclear cells; MDSC, myeloid-derived suppressor cell; HPSC, Human pluripotent stem cell; HSPC, Hematopoietic stem/progenitor cells; UCB, Umbilical cord blood; iPSC, Induced pluripotent cells; hESCs, human embryonic stem cells; ScFvs, Single-chain variable fragments; HLA-A2, Human leukocyte antigens-A2; ITAMs, immunoreceptor
}

\section{BIOLOGY OF NK CELLS}

NK cells, first identified in 1975, are innate effector lymphocytes that differ from $\mathrm{T}$ cells and $\mathrm{B}$ cells. NK cells can recognize and kill abnormal cells that lack MHC restriction or prior sensitization, and are considered as the most effective immune cell subpopulation to monitor and clear diseased cells in vivo $(18,19)$.

NK cells are developed from common lymphoid progenitor cells in the bone marrow (BM) and exist within primary and secondary lymphoid tissue, as well as within non-lymphoid tissue including the lungs, liver, and the peripheral blood (PB) (20). Of all the circulating lymphocytes, $10-15 \%$ are considered to be $\mathrm{NK}$ cells. In humans these cells are $\mathrm{CD}^{-}{ }^{-} \mathrm{CD} 56^{+}$lymphocytes, and in mice they are phenotypically $\mathrm{CD} 3^{-} \mathrm{NK} 1.1^{+}$. Human NK cells have been identified into two distinct subpopulations based on the density of CD56 on cell surface, as follows: CD56 bright $\mathrm{CD} 16^{\mathrm{dim}} \mathrm{NK}$ cells, also known as immature NK cells, are cytokine producers especially interferon gamma (IFN $\gamma$ ), which play an important role in immunomodulation; $\mathrm{CD} 56^{\mathrm{dim}} \mathrm{CD} 16^{\text {bright }} \mathrm{NK}$ cells, known as mature NK cells, are the majority (90\%) of NK cells in PB and play significant roles in mediating the immune function of NK cells (21).

NK cells play a key role in the immune innate defense systems to destroy a variety of abnormal or stressed cells $(3,4)$. Different from other lymphocytes, NK cell recognition is not controlled by antigen specificity but rather through the integration of signals from activating and inhibitory receptors, which are recruited by ligands expressed on putative target cells. The inhibitory receptors which can identify human leukocyte antigen class I (HLA-I) or class I like molecules encompass two distinct classes: the killer immunoglobulin-like receptors (KIR2DL and KIR3DL), and C-type lectin receptors CD94/NKG2A/B (2224). Because HLA-I are almost expressed on all nucleated cells, the inhibitory response, following recruitment with inhibitory receptors, serves as a recognition of "self," which dampens NK cell activation and prevent "self" lytic attack (25). Furthermore, programmed death-1 (PD-1), cytotoxic T-lymphocyte-associated protein 4 (CTLA-4), T cell immunoglobulin and mucin domain containing-3 (TIM-3), as well as T cell immunoreceptor with Ig and ITIM domains (TIGIT), act as a series of immune checkpoints and also transmit inhibitory signals when binding to their ligands. The elimination of abnormal cells is enhanced by a lack of constitutive self HLA-I. Stressed and abnormal cell recognition occurs by the stimulation of their cell surface receptors such as: KIRs (KIR2DS and KIR3DS), NKG2D, DNAX Accessory Molecule-1 (DNAM-1), killer cell C-type lectin receptor complex CD94/NKG2C, and natural cytotoxicity receptors (NKp30, NKp44, NKp46) (25).

Direct cytotoxicity for target cells by NK cells is thought to critically rely on cytolytic granules such as perforin and

tyrosine-activated motifs; PRR, Pattern recognition receptor; PAMP, Pathogen associated molecular patterns; iCasp9, Inducible caspase-9; GvHD, Graft-vs.host disease; MVB, Multi-vesicular body; TSG101, Tumor susceptibility gene 101 protein; BBB, Blood-brain barrier; BTB, blood-tumor barrier; GMP, Good manufacturing practices. 
granzymes (26). The death receptor (DR) mediated apoptotic process of abnormal or stressed cells is also a way of direct killing. The caspase enzymatic cascade induced apoptosis is triggered by the interaction between DRs (e.g., FasL, TRAIL) expressed on NK cells and their ligands on target cells (27). Another direct killing mechanism involves antibody dependent cellmediated cytotoxicity (ADCC) (19). ADCC is usually mediated by immunoglobulin $\mathrm{G}$ ( IgG) in humans. The Fab moiety and the Fc moiety of the antibody bind to the tumor-associated antigens (TAAs) on tumor cell and CD16A (Fc $\gamma$ RIIIA), the activating receptor expressed on NK cell, respectively, to form an immunological synapse between the two. Then, NK cells will be activated and secrete cytotoxic granules to kill tumor cells (For more detailed information about ADCC of NK cells, see section Use of tumor-specific antibodies to mediate ADCC of NK cells). Furthermore, NK cells can function through an indirect way by producing chemokines and cytokines to kill abnormal cells and regulate innate and acquired immune responses (28).

\section{IMMUNE-STIMULATORY MOLECULES TO BOOST THE ANTI-TUMOR ACTIVITY OF NK CELLS}

Endogenous NK cells in cancer patients usually have an impaired function because of the alteration of a repertoire of receptors in the cells. This may involve downregulation of activating receptors and/or upregulation of inhibitory receptors (7). Thus, the primary method in immunotherapy treatments is to "push" for immune activation by including additives like cytokines and antibodies that help modulate the mechanisms that improve the quantity and/or quality of the anti-tumor immune response (Figure 1A) (29).

\section{Cytokines to Argument NK Cell Activity}

Cytokines promote the survival, proliferation, differentiation and activation of lymphocytes. Interleukin (IL) $-2,-15,-12,-21$ as well as-18 improve anti-tumor function of NK cells and boost their proliferation in vitro and in vivo $(30,31)$. Here, we focus on the first two. A more detailed review can be found in Fang et al. (32), Lin and Leonard (33).

IL-2 was initially discovered as a T-cell growth factor more than 30 years ago and now is one of the most popular cytokines used to boost cytotoxicity of NK cells (30). However, a highdose IL-2 therapy can lead to severe adverse effects, including vascular leakage and organ injury caused by activation of the vascular endothelium, where the IL-2 high affinity receptor, IL$2 \mathrm{R} \alpha \beta \gamma$, is expressed (34). Furthermore, Treg cells also express high-affinity IL-2R $\alpha \beta \gamma$ receptors and are preferentially activated by IL-2, inhibiting NK cell proliferation and cytotoxicity (35). These resulted in the development of alternative forms of IL-2. A new mutant of IL-2 called "super-2" has been constructed with increased affinity for the IL-2/15R $\beta$ subunit present on NK cells, but lower affinity for IL-2R $\alpha$ subunit (36). Alternatively, variants of IL-2, such as F42K, show decreased affinity in vitro for IL-2R $\alpha$ (37). Another strategy is to create a recombinant fusion protein comprised of a cowpox virus encoded NKG2D binding protein with a mutated form of IL-2 that preferentially and potently stimulates IL-2 on cells bearing NKG2D only, without broadly activating IL-2R $\alpha$-bearing cells or inducing side effects in animal models (38).

A superior alternative to IL-2 is IL-15, which preferentially stimulates memory $\mathrm{CD}^{+} \mathrm{T}$ cells, and immature and mature NK cells. IL-15 receptors consist of IL-15R $\alpha$, IL-2/15R $\beta$, and $\gamma$ c. IL15R $\alpha$ expressed on antigen-presenting cells such as DCs and monocytes can present IL-15 in trans to IL-2R $\beta \gamma$ c receptors expressed on $\mathrm{NK}$ and $\mathrm{CD}^{+}{ }^{+} \mathrm{T}$ cells without activating Tregs (39). IL-15 is the principal $\gamma c$ family cytokine in the cytotoxicity, homeostasis and development of NK cells (30). In the first clinical trial where recombinant human (rh) IL-15 was infused to patients with metastatic malignancies, NK cell proliferation was observed in patients (40). Although two patients showed the clearance of pulmonary lesions, there were no objective responses. In addition, the clinical use of rhIL-15 might be compromised by its short half-life and poorly tolerated by patients (MTD: $0.3 \mu \mathrm{g} / \mathrm{kg} /$ day). Interestingly, rhIL-15 was found to modulate the homeostasis of NK cells, memory $\mathrm{CD}^{+} \mathrm{T}$ cells and $\gamma \delta \mathrm{T}$ cells, but not Treg cells (40). Moreover, a most recent phase I clinical trial reported that subcutaneous administration of rhIL15 significantly elevated the tolerated dose of rhIL-15 in patients with refractory solid tumor (MTD: $3 \mu \mathrm{g} / \mathrm{kg} /$ day). Subcutaneous administration of rhIL-15 remarkably promoted the proliferation of circulating NK cells and CD8 ${ }^{+} \mathrm{T}$ cells, especially CD56 $6^{\text {bright }}$ NK cells (41). The biological function of rhIL-15 allows it to be used in combination with other modalities. Indeed, there are several clinical trials (NCT03759184: obinutuzumab; NCT02689453: alemtuzumab; NCT03388632: nivolumab and ipilimumab; NCT03905135: avelumab) underway investigating rhIL-15 in combination with antibodies.

ALT-803 is a superagonist of IL-15 comprising an IL-15Ra fused to IgG1Fc which is bounded to IL-15 mutein (N72D). This special compound is designed to simulate the typical trans presentation of IL-15 and has a much longer half-life ( $25 \mathrm{~h}$ vs. < $40 \mathrm{~min})$, which may lead to enhanced ADCC $(42,43)$. In the first phase I clinical study with ALT-803, 33 patients who relapsed after allogeneic hematopoietic cell transplantation (allo-HCT) received ALT-803 intravenously or subcutaneously. ALT-803 is generally well-tolerated, as no severe dose-limiting toxicities (DLT) and graft-vs.-host disease (GVHD) were observed in both cohorts. Nineteen percent of the subjects showed clinical benefit, with 1 complete remission lasted for 7 months. All patients in this study exhibited increased levels of circulating CD56 ${ }^{\text {bright }} \mathrm{NK}$ cells and $\mathrm{CD} 8^{+} \mathrm{T}$ cells, especially those administered subcutaneously (44). Considering its prolonged half-life and potent activating power for $\mathrm{CD}^{+} \mathrm{T}$ and NK cells, ALT-803 is being evaluated in a range of ongoing clinical studies in combination with antibodies (NCT02523469: nivolumab, NCT02384954: rituximab) or adoptive transfer of NK cells (NCT01898793, NCT02782546). In a recent Phase 1b clinical trial, ALT-803 combined with anti-PD-1 antibody nivolumab was well-tolerated in non-small cell lung cancer (NSCLC) patients, and $6 / 21$ of patients showed an objective response. Notably, among 11 subjects previously treated with nivolumab alone and relapsed, 3 subjects exhibited partial response, suggesting the 


\section{A Transfer of immune stimulants}

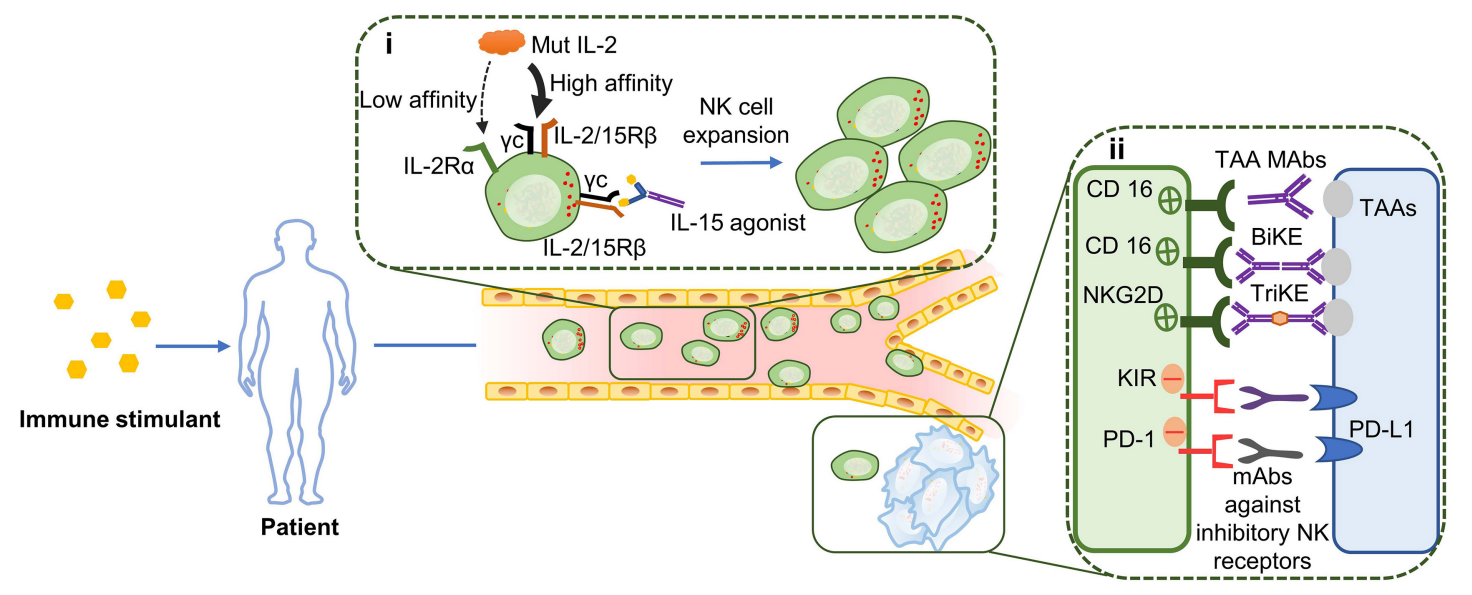

B Adoptive transfer of NK cells

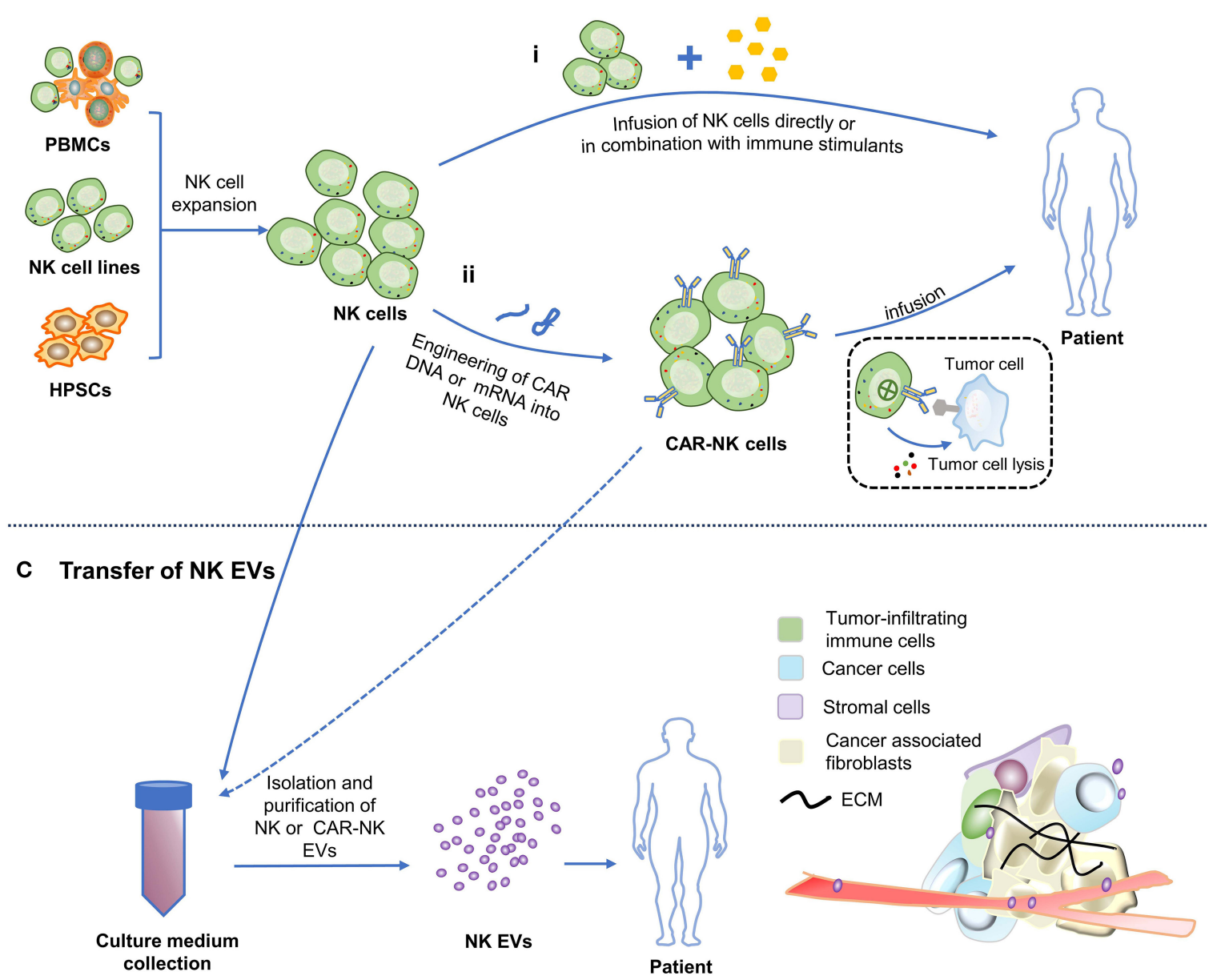

FIGURE 1 | Various NK cell-based immunotherapy approaches. (A) Administration of stimulatory cytokines and antibodies to patients triggers activation and expansion of the autologous NK cells and enhance their cytotoxicity. (i) Cytokine. "Super" agonist of IL-2 improves its affinity for IL-2/15R $\beta$. Arrow width indicates expected intensity of IL-2 signaling. The "super" agonist of IL-15 mimics the physiological trans-presentation of IL-15 to NK cells without the involvement of antigen-presenting cells. (ii) Antibodies. Binding of CD16 to the Fc portion of TAA mAbs leads to NK cells activation and ADCC. Application of BiKE or TriKE target to CD16 or NKG2D (on NK cells) and tumor antigens promotes the formation of immune synapses between NK cells and tumor cells. mAbs against inhibitory receptors 
FIGURE 1 | on NK cells facilitate NK cytotoxicity. (B) Adoptive transfer of NK cells. (i) NK cells obtained from PBMCs, NK cell lines or hPSCs can be infused into patients directly or in conjunction with immune stimulants. (ii) NK cells are designed to express chimeric antigen receptors (CAR), which are then allowed to expand ex vivo before being transfused back into the patient. (C) Infusion of engineered NK cells and NK/CAR-NK cell derived EVs. Culture medium of expanded NK cells or CAR NK cells can be exploited to isolate EVs and then infused into the patient. TAA, Tumor-associated antigen; PD-L1, Programmed death ligand-1; ECM,

Extracellular matrix.

addition of ALT-803 may reinforce the anti-tumor activity of antibodies (45). In clinical studies combining ALT-803 with adoptive transfer of NK cells (NCT01898793, NCT02782546), subcutaneously injected ALT-803 is expected to enhance the in vivo activation, survival and expansion of donor derived NK cells without severe adverse events (46). Given the fact that ALT-803 has significant anti-tumor activity and did not aggravate side effects associated with nivolumab or Bacillus Calmette Guerin (BCG) (47), meaningful results are promising to be obtained in these underway trials.

\section{Antibodies to Redirect NK Cytotoxicity}

Monoclonal antibodies (mAbs) possess strong inherent efficacy that suits cancer immunotherapy as they have been shown to directly and/or indirectly promote the roles of NK cell in vivo. In this section we will discuss tumor-specific antibodies, specific killer engagers and antibodies targeted inhibitory receptors (on NK cells).

\section{Use of Tumor-Specific Antibodies to Mediate ADCC of NK Cells}

Tumor-specific antibodies are mAbs that work partially by promoting NK cell ADCC through the binding of the IgG Fc part and its activating receptor CD16A (Fc $\gamma$ RIIIA) expressed on NK cell (48). Previously, Varchetta et al. found that trastuzumab therapy caused ADCC of NK and NKT cells in 15 of 18 patients with breast cancer overexpressing Her2, and the killing capacity of $\mathrm{CD}_{16} 6^{+}$lymphocytes depended on $158 \mathrm{~V} / \mathrm{F}$ polymorphism of CD16A (49). This study indicates that the effectiveness of short-term trastuzumab monotherapy may be associated with ADCC. However, ADCC is actually influenced by a number of factors. First, the difference in CD16A allotype affinity between cancer patients may contribute to individual heterogeneity of ADCC. Patients with CD16A 158VV alleles showed higher affinity for IgG $\mathrm{mAbs}$ than those bearing $158 \mathrm{FF}$ and $158 \mathrm{VF}$ alleles (49). Second, the quantity of NK cells and NKT cells among peripheral blood lymphocytes count for the intensity of ADCC (49). Different ADCC levels in patients have been shown to correlate to the numbers of effector cells. Third, the IgG subclasses vary in affinity to CD16A and this binding difference decides their capacity to elicit ADCC. It has been demonstrated that IgG3 and IgG1 show high affinity to CD16A, followed by IgG4, while the affinity of IgG2 toCD16A is extremely low (50). Besides, ADCC is associated with the concentration of IgG $\mathrm{mAb}$ in a dose-dependent manner. Humoral components may suppress ADCC, considering the potential competition between conventional $\mathrm{mAbs}$ and human serum IgG for binding CD16A $(51,52)$.

Some studies have focused on the modification of mAbs to enhance ADCC by increasing affinity for Fc receptors through mutagenesis or glycosylation. An Fc-engineered CD133 antibody containing the S239D/I332E substitution showed an improved affinity to NK cells and potent NK cell degranulation in a xenograft model of human acute myeloid leukemia (AML) (53). Alternatively, the transgenic chicken derived anti-CD20 mAbs presenting $14 \mathrm{~N}$-glycan patterns such as terminal galactosylation, afucosylation, and high-mannose showed significantly improved Fc-mediated roles, such as ADCC and complement-dependent cytotoxicity (CDC), compared to commercial rituximab, a chimeric $\mathrm{mAb}$ against $\mathrm{CD} 20$ (54).

Recently, Ferrari de Andrade et al. generated mAb 7C6 against MICA/B (Major Histocompatibility Complex Class-I chain related gene $A / B$ ), which could prevent the extracellular domains of MICA and MICB from proteolytic shedding and mediated antitumor immunity by activation of NKG2D and CD16 on NK cells. In a metastasis model pretreated with human NK cells, mAb 7C6 effectively inhibited tumor growth in vivo (55).

Immunocytokines are another choice. For instance, hu14.18IL2 is a humanized $\mathrm{mAb}$ that is covalently linked to two molecules of IL-2 at the Fc region. It has been demonstrated that it effectively treats patients with advanced melanoma or neuroblastoma (56).

\section{Use of Bi- or Tri-specific Killer Engagers to Potentiate NK Cell Activity}

Bi-specific or tri-specific killer cell engagers (BiKEs or TriKEs) are designed moieties containing single-chain variable fragments $(\mathrm{scFv})$ against both TAAs and activating receptors on NK cells to create an immunologic synapse between NK cells and tumor cells (57).

CD16 is an attractive candidate for mediating NK celldependent tumor cell killing. It has been demonstrated that CD16-directed bi-specific $(\mathrm{CD} 16 \times 19)$ and tri-specific $(\mathrm{CD} 16 \times 19 \times 22) \mathrm{scFv}$ agents directly stimulate NK cells via CD16, potentiating NK cell lytic activity and cytokine release to attack lymphoid tumors $(58,59)$. Another novel BiKE antibody, $\mathrm{CD} 16 \times 33 \mathrm{BiKE}$, signals via CD16 and targets the myeloid differentiation antigen CD33. It could specifically trigger the lytic activity of NK cells and the release of cytotoxic granules to fight against AML cells in vitro. Besides, in the same study, it was found that addition of the ADAM17 inhibitor, which prevents CD16 shedding, can enhance the effector roles of NK cells (60). NKG2D, a lectin-type receptor and one of the major activating NK cell receptors, is another powerful candidate for mediating NK cell immune surveillance. A CS1-NKG2D bi-specific antibody, containing an anti-CS1scFv and an antiNKG2D scFv, displayed a dose-dependent increase in specific cytotoxicity of NK cells as well as cytokine production in vitro, and significantly prolonged survival in a human multiple myeloma (MM) model (61). 
In recent years, modified killer cell engager antibodies have been developed in terms of design and structure. For instance, AFM13, a tetravalent bi-specific tandem antibody against CD16A and CD30, works in an Fc-independent manner with high affinity without Fc domains binding to CD16A. Due to its molecular weight of $104 \mathrm{kDa}$ (BiKE/TriKE: 50-75 kDa), AFM13 has a longer half-life than other bi/tri specific antibodies. Its tolerability and safety have been tested in relapsed/refractory Hodgkin lymphoma patients, with $77 \%$ of subjects showed disease stable $(62,63)$. It is currently under evaluation in a phase II monotherapy trial in relapsed/refractory Hodgkin lymphoma patients (64). TriKEs are developed on the format of BiKEs. Improvements in newer generation TriKE include promoting specificities to targets, modifying scFvs with high affinity to NK cells, as well as enhancing the self-sustaining of NK cell activity (65). For instance, a modified IL-15 crosslinker has been integrated into TriKE to enhance the survival and expansion of NK cells in vivo $(66,67) .161533$ TriKE, consisting of anti-CD16 scFv, a modified IL-15 linker and antiCD33 scFv, could direct antigen specific ADCC while increasing both NK cell survival and proliferation against AML in vivo (66). 1615EpCAM TriKE (CD16×IL-15×Epcam) significantly enhanced NK cell proliferation, lytic degranulation and cytokine secretion in vitro (67).

Although the BiKE/TriKE therapies have the capability to redirect NK cytotoxicity, enhance NK function, as well as can be exploited in combination with existing cancer immunotherapies, there are still many obstacles impeding their clinical application. Challenges to successful translation of BiKE/TriKE may include the structure design, such as the identification of TAAs and selection of appropriate joint linker $(68,69)$. Suitable TAAs could help reduce the off-target effects of these engineered molecules, which is also important for the clinical translation of CAR$\mathrm{T}$ therapy. On the other hand, the joint linkers selected in $\mathrm{BiKE} /$ TriKE have the potentials to dominate the biodistribution of entire molecules, which may either increase or decrease their tumor targeting ability. It is reported that cytokine portion can affect the whole immunocytokine molecule to recognize irrelevant antigen, indicating the careful assessment of the biodistribution is crucial for the format design (70). Another challenge is the production technology. Although protein yields have been improved with the development of expression system, cost-efficient and high-yield manufacturing remains a problem (71).

\section{Targeting the Immune Checkpoints to Release the Inhibition on NK Cells}

The purpose of antibodies targeting inhibitory NK cell receptors, especially immune checkpoint-targets, is to unblock a blocked immune response to increase anti-tumor activity. This is different from NK cell "enhancers" who activate the immune system to improve anti-tumor responses.

One of the main types of inhibitory receptors is inhibitory killer-cell immunoglobulin-like receptors (KIRs), which could be targeted by IPH2101 and IPH2102 (lirilumab) antibodies. IPH2101 and IPH2102 are clinical grade immunoglobulin G4 (IgG4) mAbs which interact with KIR2D moieties. In vitro, they augment NK cell-mediated killing against KIR-ligand expressing and antibody coated tumor cells $(72,73)$. The tolerability and safety of IPH2101 were confirmed by Phase I clinical trials in patients with AML or relapsed/refractory MM $(74,75)$. However, IPH2101 only induced insufficient clinical response in a Phase II clinical trial in patients with smoldering MM (76). Carlsten et al. demonstrated that IPH2101 infusion led to significant decrease in both KIR2D expression on NK cells and NK cell responsiveness, which might be the underlying mechanism behind the low therapeutic efficacy of IPH2101 (77). The loss of KIR2D on NK cells induced by IPH2101 was mediated by trogocytosis, a mechanism whereby activated neutrophils and Fc $\gamma$ RI expressing monocytes extracted KIR2D from the NK cells and expressed this antibody-targeted molecule on their own surface. These findings suggest that the application ofIPH2101mediated KIR2D blockade in vivo might be restricted by the loss of KIR2D on NK cells and subsequent hyporesponsiveness to anti-KIR antibody. As a human IgG4 mAb derived from recombinant chinese hamster ovary cells, IPH2102 (lirilumab) shares the primary amino acid sequence with IPH2101, with the exception of a mutation incorporated at the heavy chain constant region, by the substitution of serine for proline. In a first-inhuman, phase I trial using high lirilumab doses in patients with high sensitivity to NK cell modulation, no dose-limiting toxicity recorded (78). Thus, further investigation should examine the efficacy of IPH2101 and IPH2102 in different disease settings as well as their therapeutic value when combined with other therapies, e.g., cytokines or tumor-targeting mAbs.

IPH2201 (humZ270), a mAb bound to NKG2A, showed enhanced NK cytotoxicity to Epstein-Barr virus (EBV) cell lines or engrafted human primary leukemia in vivo (79). There are ongoing clinical trials aimed at testing its safety, tolerability and efficacy when used singly or when co-administered with other therapies (www.clinicaltrials.gov).

PD-1 is an inhibitory receptor expressed by some activated lymphocytes, including $\mathrm{B}$ cells, $\mathrm{T}$ cells, and NK cells. PD-1 can be induced on NK cells from cancer patients, and induces functional failure of activated NK cells. This has led to the design of many PD-1 antibodies, including nivolumab, pidilizumab, and pembrolizumab (80). Current research is focused on PD1 antibodies that can inhibit tumor growth by eliminating $\mathrm{T}$ cell immunosuppression, so it is worth exploring the enhanced endogenous NK cell cytotoxicity by PD-1 antibodies.

Another inhibitory receptor found on cell surface of NK cells and T cells is TIGIT. It has been reported that blocking TIGIT is an alternative complementary strategy to the currently available immunotherapies. In a recent study, using tumor-bearing mice, Zhang et al. found that inhibition of TIGIT enhanced NK cellmediated tumor immunity and blocked NK cell exhaustion, further improving memory responses to tumor re-challenge in an NK cell-dependent way (81). Several other checkpoint proteins including LAG-3(lymphocyte-activation gene 3), TIM-3 and CD96 are also present in NK cells (82).

\section{ADOPTIVE NK CELL IMMUNOTHERAPY}

Adoptive transfer of NK cells with high yields and high quality is a direct and fundamental approach to replacing, restoring and improving the function of the immune system through 
infusing allogeneic NK cells activated ex vivo or chimeric antigen receptor (CAR) modified NK cells, and has been demonstrated to be a promising cellular immunotherapy against tumor cells (Figure 1B).

\section{Adoptive Transfer of Unmodified NK Cells}

Adoptive transfer of autologous NK cells expanded ex vivo for treatment patients with lymphoma, colon cancer, breast cancer and lung cancer have been tested in a range of clinical trials. Only very limited antitumor effect was observed (8385). The major reason was that the inhibitory receptors on autologous NK cells matched self MHC class I presented on tumor cells, and this "self" recognition signals subsequently inhibited the activation of NK cells (86). Besides, autologous NK cells derived from cancer patients were actually in an immune suppression state with impaired functions, making these cells difficult to exhibit antitumor capability. The first piece of evidence showing that NK cells had a clinical benefit was reported in 2002 (87). It has comfirmed that donor-vs.recipient NK cell alloreactivity, which was mainly resulted from KIR ligand incompatibility, could avoid relapse and graft rejection without GVHD in AML patients receiving HLA (Human leukocyte antigens) mismatch donor hematopoietic transplantation (87). Later, this strategy was used in adoptive cellular immunotherapy of ex vivo activated allogeneic KIR/KIR ligand mismatched NK cells derived from PBMC into AML patients (88). Subsequently, alloreactive PBMC derived NK cells have been widely investigated as an immunotherapy in clinical trials of hematologic malignancies, as well as in trials of solid tumors including melanoma, breast cancer, ovarian cancer, neuroblastoma, renal cell carcinoma, colorectal cancer, and hepatocellular cancer $(89,90)$. The rules for infusion of allogeneic NK cells as cancer treatment have been reviewed by Leung Wing (91). For manufacturing large numbers of alloreactive NK cells prior to reinfusion, cytokines such as IL-2 and IL-15 were initially used for ex vivo culture and expansion of primary NK cells from peripheral blood (PB) (92). However, it was difficult to obtain large numbers of functional NK cells by only exposure to cytokines. Subsequently, artificial antigen-presenting cells (aAPCs) were developed as feeder cells for expanding NK cells ex vivo. Our group developed K562-based aAPCs with CD137L-IL-21, and found that they facilitate the log growth phase of NK amplification without indication of senescence in vitro culture (Invention patent NO. ZL201110075736.1). Using the aAPCs with CD137L-IL21 as feeder cells, a closed, largescale and automated bioreactor under GMP conditions can be successfully used for manufacturing large numbers of activated NK cells, which has significantly promoted clinical trials for the application of NK cell-based immunotherapy.

The second way to produce large numbers of cytotoxic NK cells for immunotherapy is through a clonal NK cell line, such as NK-92, KHYG-1, HANK-1, NKG, NK-YS, YTS, YT, NK3.3, and NKL, all of which can expand and propagate easily in culture medium (93). Among them, NK-92 is the only cell line approved by the US FDA for use in the clinical trials, though these EBV-transfected cells must be irradiated before adoptive transfer to prevent propagation in patients (94). NK-92 cells can easily proliferate in flasks, gas-permeable bags, or bioreactors in compliance with GMP, with a doubling time between 24 and $36 \mathrm{~h}$ to produce effective clinical-grade NK-92 effectors (93). Although the safety and tolerability of NK-92 cells have been tested in several Phase I clinical trials, limited data exist on their clinical benefits (94-96). In a recent dose escalation trial (NCT00900809), the feasibility of adoptive transfer of NK92 cells was assessed in 7 patients with refractory/relapsed AML. None of the patients experienced DLT, while no one had complete remission. Besides, no significant changes were observed in either counts or activity of NK cell, CD8+ T cell, CD4+ T cell, T regulatory cell and myeloid-derived suppressor cell (MDSC) (97). It has been indicated that the limited clinical efficiency of NK-92 cells is mainly due to the lack of CD16 expression and their short longevity in vivo (32). To overcome these barriers, high affinity natural killer (haNK) cells, a variant of NK-92 cell line engineered to CD16A (158VV) receptor and endogenous IL-2, has been successfully developed. This variant can mediate ADCC as well as bypass the need for exogenous IL-2 in culture (98). The feasibility of haNK cells is currently under investigation in patients with solid tumors (NCT03027128). Moreover, target-activated NK-92 (taNK) cells, another engineered variant of NK-92 cells modified with CARs, have been designed to target TAAs-expressing tumor cells (99, 100). The stable CAR expression and activity of these cells have been demonstrated by HER2.taNK (HER2-specifc targetactivated NK), a cell line that is now being tested in patients with recurrent HER2-positive Glioblastoma (NCT03383978).

The third source of NK cells for tumor lysis are NK cells differentiated from human pluripotent stem cells (hPSCs), including hematopoietic stem/progenitor cells (HSPC) from umbilical cord blood (UCB), induced pluripotent stem cells (iPSCs), and human embryonic stem cells (hESCs) (101-103). NK cells derived from hPSCs can be utilized as an allogenic product. The protocols for producing NK cells from hPSCs often involve separating or generating CD34+ hematopoietic precursors and culturing in the presence of NK cell maintaining cytokines (IL-3, IL-7, IL-15, SCF, FLT3L) to further stimulate differentiation and growth of NK cells (104). These NK cells can be expanded by coculturing with aAPCs, which resulted in a 2-3 log expansion that lasted for more than 2 months (105). NK cells differentiated from stem cells have a phenotype close to primary NK cells, a stronger proliferative ability and a homogenous, genetically defined population which meets the requirements of their clinical applications $(103,104,106)$. Recently, it has been demonstrated that long-term cryopreservation (1-10 years) had no effect on the expansion potential and effector function of UCB-derived NK cells, which made UCB an emerging source of NK cells. Particularly, there are over 600,000 UCB -units stored globally (107). The safety and tolerability of some UCB-derived NK cells have been tested in phase I clinical trial against AML and myelodysplastic syndromes (108).

In order to obtain stronger tumor killing activity of transferred NK cells, immune-stimulatory molecules such as antibodies and cytokines are often used in combination with NK cells in clinical studies $(89,109)$. Moreover, considering that NK cells can modulate host immune system against cancers, and hence 
function as immune adjuvants, they are able to boost the efficacy of anticancer therapy when combined with traditional treatments such as chemotherapy. In several clinical trials on NK cellbased immunotherapy, patients received chemotherapy prior to NK cell infusion (www.clinicaltrials.gov). Particularly, several drugs used in cancer chemotherapy could stimulate expression of activating ligands on tumor cells, which makes tumor cells more sensitive to NK cell-mediated cytotoxicity. Some of these drugs may also promote the recruitment of NK cells to the tumor sites by increasing secretion of selected chemokines (110). Among them, lenalidomide seems to be the most active drug which overcomes suppression of human NK cell anti-tumor functions by TME-associated IL- 6 and TGF- $\beta$ and lowers the threshold of MICA for NKG2D-mediated NK cell activation and augments nanoscale rearrangements in cortical actin at the NK cell ADCC immune synapse $(111,112)$. In clinical settings, the clinical trials of expanded and activated NK cell adoptive transfer are always in conjunction with lenalidomide treatment (NCT02573896, NCT02280525, NCT02481934, NCT02525250).

\section{Adoptive Transfer of CAR-NK Cells}

Unlike immunostimulatory strategies which involve the delivery of molecules to assist NK cells, genetic modification strategies induce changes in the genetics of NK cells directly, leading to far-reaching and sustained changes to the cells (113). Among them, genetic modification of NK cells with CAR constructs has drawn increasing attention. CAR-NK cells can be produced from different sources of NK cells including primary NK cells, NK cell lines, and HPSCs. CAR-NK has adopted the basic structural framework of CAR-T, that is, chimeric antigen receptors mainly composed of extracellular, hinge, transmembrane and intracellular domains, as well as the transfection methods $(100,114,115)$. The extracellular domain can bind tightly to tumor-associated antigens expressed on the surface of tumor cells, which determines the specificity of CAR structures. Single-chain variable fragments (ScFvs) are the most commonly used ectodomains for CARs. The hinge domain is the connecting sequence between the extracellular domain to the transmembrane domain, which endowed CAR with sufficient orientation and flexibility to bind to tumor antigens and are expected to impact the CAR-NK activities. The transmembrane domain lies between the hinge and the

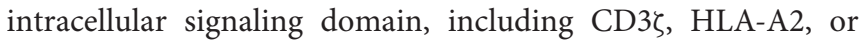
CD28 molecules. The structure of the intracellular signaling domain determines the intensity of the CAR-NK activation signal, which contains the immunoreceptor tyrosine-activated motifs (ITAMs). The majority of current CAR endodomains contain an activation region derived from $\mathrm{CD} 3 \zeta$, which is the most classical intracellular domain including three ITAMs. In order to increase the proliferation and cytotoxicity of CAR modified effector cells, co-stimulatory protein receptors such as CD28, 4-1BB, CD134, ICOS are added to the cytoplasmic tail.

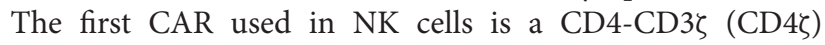
fusion receptor, which was reported by Tran et al. (116). In this study, the $\mathrm{CD} 4 \zeta$ chimeric receptor is biochemically and functionally active and can guide human NK cells efficiently to kill either $\mathrm{HIV}$-infected $\mathrm{CD}^{+}{ }^{+} \mathrm{T}$ cells or NK-resistant tumor cells expressing gp120 in vitro, indicating CAR structure can be successfully expressed on NK cells, leading to efficient retargeting (116). Subsequently, more attempts were taken to enhance the anti-tumor ability of NK cells. Uherek et al. modified NK-92 cells with ErbB2-specific CAR, and found these cells show specific cytotoxicity in animal models (117). While, Imai et al. evaluated the efficacy of primary NK cells expressing CD19 CAR against autologous leukemic cells in vitro, and demonstrated these cells can bypass inhibitory signals (118). To date, CAR-NK cells have been evaluated for the treatment of hematological cancers and solid tumors in preclinical studies with numerous good results [reviewed in $(32,36,100)]$. On the basis of these findings, the clinical translation of CARNK cells has witnessed significant interests (see Table 1 for details of ongoing clinical trials). Although CAR-NK therapy is still under clinical evaluation, $\mathrm{NK}$ cells possess several advantages over $\mathrm{T}$ cells in being engineered to express CARs and used for cancer treatment. First, NK cells are easy to be isolated and have a relatively short lifespan. Therefore, the risk of overexpansion of transferred CAR-NK cells in patients is relatively low. Second, the cytokines secreted by NK cells mainly include IFN- $\gamma$ and GM-CSF, which are relatively safer than those released by activated CAR-T cells, e.g., TNF- $\alpha$ and IL-6. In particular, the proinflammatory cytokines produced by CAR$\mathrm{T}$ cells may cause life-threatening cytokine release syndrome (CRS), a most common and severe side effect of CAR-T therapy (119). Third, CAR-NK cells could trigger the lysis of target cells in both CAR-dependent and CAR-independent manners, which further potentiating their killing activity. In addition, CAR-NK therapy is expected to be less expensive, considering that NK cells can be derived from PBMCs, NK cell lines and hPSCs. However, $\mathrm{T}$ cells used for CAR-T therapy are required to be autologous $(119,120)$.

Despite of the significant advantages and great potentials, there are still challenges that should be addressed carefully to prevent hindering the clinical application of CAR-NK therapy. First, design of the optimal structure of CARs on NK cells has not been systematically studied yet. The position of the CARbinding epitope and its distance to the CAR-NK cell surface are expected to affect the binding to the antigens, the optimal formation of immune synapses and CAR-NK cells activation (100). Empirical observations from CAR-T cells indicate that the structure of the hinge and transmembrane domains can affect CAR specificity and activity. In addition, there is a differential requirement for costimulatory signals between the established NK-92 cell line, primary NK cells and hPSC-derived NK cells. The study with three kind CD19-specific NK-92 cells, whose CARs harbor the same anti-CD19 $\mathrm{scFv}$ and hinge region, but linked to human $\mathrm{CD} 3 \zeta$, composite $\mathrm{CD} 28-\mathrm{CD} 3 \zeta$ or $4-1 \mathrm{BB}$ $\mathrm{CD} 3 \zeta$ extracellular domains, respectively, showed that 4-1BBCD3 $\zeta$-based CD19-specific NK-92 cells were less effective than $\mathrm{CD} 3 \zeta$ or $\mathrm{CD} 28-\mathrm{CD} 3 \zeta$ in cytotoxicity and cytokine production $(121,122)$. While for CD19-specific primary NK cells expanded ex vivo, inclusion of $4-1 \mathrm{BB}$ or $2 \mathrm{~B} 4$ costimulatory domains together with $\mathrm{CD} 3 \zeta$ was shown to promote both cytokine production and specific cytolysis $(116,123)$. It is also notable that, recently, Li et al. expressed CAR constructs which were 
TABLE 1 | Current clinical trials of CAR-NK cells.

\begin{tabular}{|c|c|c|c|c|c|c|c|}
\hline $\begin{array}{l}\text { ClinicalTrials.gov } \\
\text { Identifier }\end{array}$ & Trial & Status & Phase & NK source & Target & $\begin{array}{l}\text { Signaling domain of } \\
\text { CAR }\end{array}$ & Institute \\
\hline NCT02742727 & $\begin{array}{l}\text { CAR-pNK cell immunotheray in } \\
\text { CD7 positive leukemia and } \\
\text { lymphoma }\end{array}$ & Recruiting & $|/| \mid$ & NK-92 & $\mathrm{CD7}$ & CD28-4-1BB-CD3ל & $\begin{array}{l}\text { PersonGen BioTherapeutics } \\
\text { (Suzhou) Co., Ltd. Suzhou, } \\
\text { Jiangsu, China }\end{array}$ \\
\hline NCT02892695 & $\begin{array}{l}\text { PCAR-119 bridge immunotheray } \\
\text { prior to stem cell transplant in } \\
\text { treating patients with CD19 } \\
\text { positive leukemia and lymphoma }\end{array}$ & Recruiting & $|/| \mid$ & NK-92 & CD19 & CD28-4-1BB-CD3ל & \\
\hline NCT02839954 & $\begin{array}{l}\text { Study evaluating the efficacy and } \\
\text { safety of chimeric antigen } \\
\text { receptor-modified pNK cells in } \\
\text { MUC1 positive advanced } \\
\text { refractory or relapsed Solid } \\
\text { Tumor }\end{array}$ & Recruiting & $|/| \mid$ & NK-92 & MUC1 & - & \\
\hline NCT03056339 & $\begin{array}{l}\text { Dose escalation study phase I/II } \\
\text { of umbilical cord blood-derived } \\
\text { CAR-engineered NK cells in } \\
\text { conjunction with } \\
\text { lymphodepleting chemotherapy } \\
\text { in patients With } \\
\text { relapsed/refractory B-Lymphoid } \\
\text { malignancies }\end{array}$ & Recruiting & I/II & HSPC & CD19 & CD28- CD3 $\zeta$ & $\begin{array}{l}\text { University of Texas MD } \\
\text { Anderson Cancer Center } \\
\text { Houston, Texas, } \\
\text { United States }\end{array}$ \\
\hline NCT03579927 & $\begin{array}{l}\text { Combined therapy of } \\
\text { CAR.CD19- CD28-CD3ร-2A- } \\
\text { iCasp9-IL15-transduced cord } \\
\text { blood NK cells, high-dose } \\
\text { chemotherapy, and stem cell } \\
\text { transplant in Treating participants } \\
\text { with B-cell lymphoma }\end{array}$ & $\begin{array}{l}\text { Not yet } \\
\text { recruiting }\end{array}$ & $1 / 11$ & HSPC & CD19 & CD28- CD3 $\zeta$ & \\
\hline
\end{tabular}

specifically tailored to promote NK cell activation in iPSCderived NK cells. They showed that such constructs containing the transmembrane NKG2D and intracellular 2B4 domains exhibit superior performance compared to CAR constructs designed for T cells (124). Given the unique activating receptor repertoire and signal-activating proteins of NK cells, customizing NK-based CAR structures will have great potential for improving CAR-NK function.

Second, although optimization of transduction methods in the last few decades has led to higher efficiencies, retroviral transduction is dependent on the existence of an active cell division, which weakens the efficiency of this strategy with nonactivated NK cells. Genotoxicity of insertional mutagenesis is still a potential safety concern for lentiviral vectors. Furthermore, NK cell death associated with these procedures has limited the use of genetically engineered NK cells. Only few investigations have documented results regarding the capability of NK cells to function successfully after viral transduction. The innate properties that characterize NK cells may result in their reduced efficacy after viral transduction and apoptosis. As part of the immune systems innate defense mechanisms, pattern recognition receptors (PRRs) are used to identify pathogen associated molecular patterns (PAMPs). These procedures are likely involved in triggering a cascade of cellular events that lead to apoptosis of NK cells after viral transduction (125). Nevertheless, RNA engineering gave NK cells higher survival rates and transfection efficiency compared to viral gene transfer. One study found that NK cells differentiated from gene modified human hematopoietic stem cells have high gene transfer efficiency and viability of CAR-NK cells (126).

Third, albeit the primary targets of CARs are antigens expressed on abnormal cells, most currently available CARs are 
directed against non-mutated autoantigens that are differentially expressed on cancer cells. This may result in non-specific binding of CARs to antigens expressed on normal tissues. Therefore, antigen-positive healthy tissues are at risk of accidental injury induced by off-target activity. Anti-CD19 T cell therapy for B cell malignancies has shown strong off-target toxicity against normal CD19-positive B cells (127). There is no clinical data to assess the extent of off-target toxicity of CAR-NK, but identification of specific tumor targets is the basis for a safe and effective CAR construct. To increase the specificity and safety of CAR molecules, the experience from CAR-T studies can be useful. Effective reduction of cytotoxicity occurs if two individual structures, or two extracellular domains, are combined in a tandem form to produce a bi-specific CAR molecule (128-130). Importing a suicide gene, such as inducible caspase-9 (iCasp9) (131), facilitates control of dosage for CAR activity and provides another strategy to mitigate toxicity. A similar concept was described with a split CAR construct that requires dimerization of a small molecule to form a functional unit, further increasing safety (132).

Another safety concerning is that the infused expanded allogenic NK cells derived products may be contaminated by $\mathrm{T}$ or B cells, theoretically resulting in GVHD or post-transplant lymphoproliferative disorders, respectively. One study reported that donor-derived, IL-15/4-1BBL-activated NK cells infused early after major histocompatibility-matched, T-cell-depleted peripheral blood stem cell transplantation in patients could cause acute GVHD (133). They also demonstrated that GVHD was highly frequent in matched unrelated donor transplants and linked to higher CD3 chimerism. This later aspect refers to the establishment of an optimal clinical-grade protocol for purification of activated $\mathrm{CD}_{5} 6^{+} \mathrm{CD} 3^{-}$NKs. This protocol could be safer for patients even in the presence of transfused third party NK cells modified with CARs. In any case, it is encouraging to note that clinical studies of haploidentical and UCB-derived NK cell infusions in hundreds of patients with both hematologic and solid malignancies have not reported a higher risk of GVHD (32).

\section{CELL-FREE DERIVATIVES FROM NK CELLS FOR CANCER IMMUNOTHERPY}

Currently, cancer immunotherapy strategies are dominated by immune cells. However, there are limitations when using immune cells directly for the treatment of cancers. For instance, immune cells can hardly penetrate into solid tumor, leading to unsatisfactory therapeutic effects. Moreover, the cost for producing, preserving and transporting clinical grade living immune cells is high, posing a challenge to wide applications in clinics. In recent years, EVs, a nano-sized vesicles naturally secreted by many different types of cells including NK cells, have gradually been proposed and studied, providing a new cell-free immunotherapy avenue (Figure 1C).

\section{Biology of NK EVs}

EVs are used to depict three types of vesicles with lipid bilayer membrane. Exosomes are the smallest membrane vesicles (40$100 \mathrm{~nm}$ ) that are secreted by most cell types by multi-vesicular bodies (MVBs) fusing with the cell membrane. Microvesicles (MV, $50 \mathrm{~nm}-1 \mu \mathrm{m})$ are vesicles that a little larger than exosomes, budding outwards from the plasma membrane. Apoptotic bodies $(50 \mathrm{~nm}-5 \mu \mathrm{m})$ are the third kind of EVs, which are generated from cells undergoing apoptosis, by an outward blebbing way. In this review, we defined "EVs" as small extracellular vesicles with nanometer size. In transmission electron microscopy images, EVs usually appear as cup-shaped entities (Figure 2A). EVs express both common biomarkers, such as tumor susceptibility gene 101 protein (TSG101) and tetraspanins (CD9, CD63, CD81, and CD81), and specific proteins based on their cell origin (134). For instance, EVs derived from human NK cells (NK EVs) contain not only typical NK markers (e.g., CD56), but also lytic proteins (e.g., FasL, perforin).

EVs are involved in a number of key cellular processes due to their ability to transfer bioactive cargos (i.e., nucleic acids, lipids, and proteins) to recipient cells or by activating signaling pathways in target cells (135-138). Therefore, they are considered as potential alternatives to cell-based therapeutics, with characteristics possibly superior to cells in some aspects. First, since EVs are nano-sized, they can diffuse through tissues passively, partly due to the leaky vasculature of the tumor and subsequent enhanced retention effect (139). Second, although the acidic environment of solid tumors caused by hypoxiaischemia increases immunosuppression $(140,141)$, it is beneficial to promote the fusion between EVs and tumor cells (142). Third, these "nano bullets" have an advantage in their ability to traverse biological barriers such as the blood-brain barrier (BBB) and the blood-tumor barrier (BTB), which has provided a completely different methodology compared to the cell-based approach (143-145). Moreover, EVs are stable at $-80^{\circ} \mathrm{C}$, lasting up to 12 months (146). This makes EVs easy to store and readily accessible as "off-the-shelf" supply.

\section{Anti-tumor Activity of NK EVs}

The first study on NK EVs study was conducted by Lugini et al. (147). In this study, it was demonstrated that isolated NK EVs from purified NK cell culture exerted a cytotoxic effects on malignant hematologic cell lines, but not on solid tumor cells like breast carcinoma SKBR3 (147). Later, activated NK EVs, obtained from large scale isolation of in vitro expanded NK cells, showed significant cytotoxic effects on a series of cancer cell lines, including ALL, neuroblastomas, and breast carcinomas (146). These findings suggest that activated NK cells may produce EVs with higher immune activity compared with naïve NK cells. The antitumor effect of NK EVs is further supported by two recent in vivo studies. In one study, NK EVs were isolated by density gradient ultracentrifugation from NK-92 cells, and then injected into melanoma locally in a mice model. As a result, the progression of tumors treated with NK-92 EVs were significantly inhibited (148). In another study conducted by the same group, NK EVs prepared in the same way were used for the treatment of glioblastoma xenograft tumors. The intravenous administration of NK EVs not only significantly suppressed tumor growth, but also exhibited tumor-specific accumulation and an ability to cross the BBB. Encouragingly, this tumor-specific accumulation persisted for more than 5 days (149). 


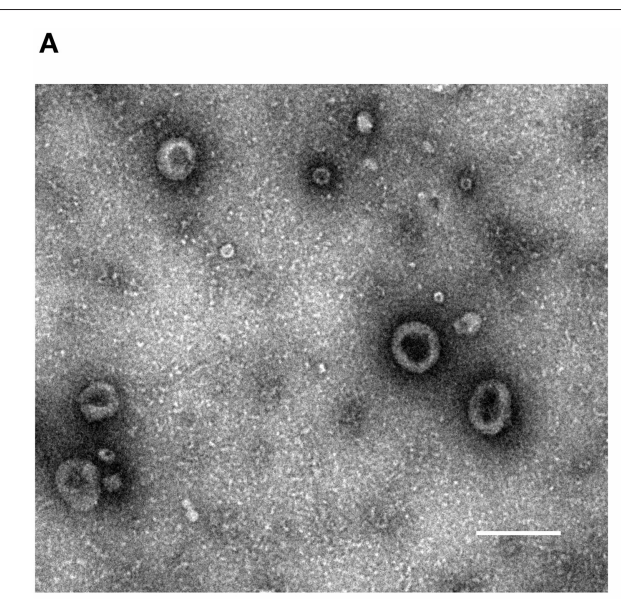

B

\section{Known mechanisms of NK EVs interacting with target cells}

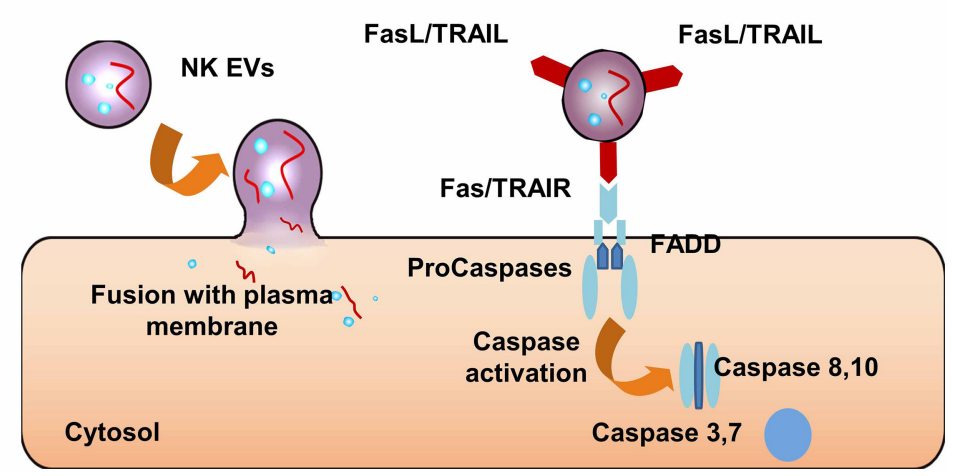

FIGURE 2 | Characteristics and anti-tumor mechanisms of NK EVs. (A) A typical micrograph of transmission electron showing extracellular vesicles obtained from NK cells; scale bar, $200 \mathrm{~nm}$. (B) Mechanisms by which NK EVs may interact with target cells.

Fais et al. reported that NK EVs could trigger the death of target cells by two distinct mechanisms $(137,150)$, including ligand-receptor interactions $(151,152)$ and plasma membrane fusion (142) (Figure 2B). Furthermore, caspases, the initiator and executioner, were involved in the cell killing mediated by NK EVs (Figure 2B). Wen et al. extrapolated that the killing mechanisms of NK EVs can be classified into three groups, including perforingranzyme mediated entry, receptor-ligand mediated interaction and granulysin mediated action (153). However, the underlying mechanisms of specific killing of tumor cells mediated by NK EVs remains unclear. NK cells recognize target cells for killing by a "self-missing" mechanism, but there is no evidence to prove that EVs can activate signaling pathways like living immune cells do. One possible reason why NK EVs can have a targeting effect is that the acidic microenvironment of solid tumors can promote the fusion of exosomes. In the study by Lugini et al. mentioned above, the secretion of NK EVs was stable and had a killing effect on activated PBMC cells in vitro, suggesting that NK EVs behave like a large "reservoir" to regulate the balance of immune cells (147). This mechanism is still not being clearly delineated. However, its potential for application in autoimmune diseases that result from excessive immune activation is obvious, as well as its potential use for elimination of side effects of immunotherapy such as cytokine storms is also worth exploring.

Notably, even though their anti-tumor activity has been demonstrated in vitro and in vivo, NK EVs have no impact on normal cells (147). In addition, due to the protective barrier offered by a natural vesicle structure, NK EVs might be used as a promising delivery system, which can be loaded with various therapeutic substances, e.g., genes and proteins. Particularly, the surface of EV membrane can be further modified by other functional groups.

\section{PERSPECTIVE}

Cancer immunotherapy strategies are evolving around different immune cells. Although the developments in the field used to be slow, a rising number of approaches are being actively exploited to boost NK cell-based anti-tumor immune functions. Immune-stimulatory molecules can either selectively enhance NK cell activity while maintaining their in vivo survival and proliferation (e.g., cytokines), or mediate NK cell cytotoxicity by ADCC (e.g., antibodies). With the advances in ex vivo expansion/activation technology, as well as new approaches to genetically modify NK cells, adoptive transfer of NK cells holds promises to become powerful weapons in the fight against cancers. Moreover, EVs derived from NK cells have become a rising star and caught more and more attentions. Because of their nanometer size and the propensity to travel and survive in the acidic tumor microenvironment, NK EVs might be potent for the treatment of solid tumors. In particular, the homologous nature of $\mathrm{NK}$ cells provides great advantages for the clinical translation of NK-cell based therapeutic approaches.

\section{AUTHOR CONTRIBUTIONS}

All authors were involved in the concept and design of the manuscript, search, and analysis of the literature. WH and GW drafted the initial version of the manuscript with support from all other co-authors. All authors revised and approved the final version of the manuscript.

\section{FUNDING}

This work was supported by the National Natural Science Foundation of China (NSFC 81672474, 21722405, and 21574118), the Zhejiang Provincial Natural Science Foundation for Distinguished Young Scientists (No. LR16H160002), Open Foundation from Key Laboratory of Tumor Molecular Diagnosis and Individualized Medicine of Zhejiang Province (No. ZJZLSYS001), and the Startup Foundation for Talented Scholars of Zhejiang University (No. 119000-193820101). 


\section{REFERENCES}

1. Pardoll DM. The blockade of immune checkpoints in cancer immunotherapy. Nat Rev Cancer. (2012) 12:252-64. doi: 10.1038/nrc3239

2. Porter DL, Levine BL, Kalos M, Bagg A, June CH. Chimeric antigen receptormodified T cells in chronic lymphoid leukemia. N Engl J Med. (2011) 365:725-33. doi: 10.1056/NEJMoa1103849

3. O’Sullivan TE, Sun JC, Lanier LL. Natural killer cell memory. Immunity. (2015) 43:634-45. doi: 10.1016/j.immuni.2015.09.013

4. Vivier E, Raulet DH, Moretta A, Caligiuri MA, Zitvogel L, Lanier LL, et al. Innate or adaptive immunity? the example of natural killer cells. Science. (2011) 331:44-9. doi: 10.1126/science.1198687

5. Grossenbacher SK, Canter RJ, Murphy WJ. Natural killer cell immunotherapy to target stem-like tumor cells. I ImmunoTher Cancer. (2016) 4:2. doi: 10.1186/s40425-016-0124-2

6. Melero I, Rouzaut A, Motz GT, Coukos G. T-cell and NK-cell infiltration into solid tumors: a key limiting factor for efficacious cancer immunotherapy. Cancer Discov. (2014) 4:522-6. doi: 10.1158/2159-8290.CD-13-0985

7. Guillerey C, Huntington ND, Smyth MJ. Targeting natural killer cells in cancer immunotherapy. Nat Immunol. (2016) 17:1025-36. doi: 10.1038/ni.3518

8. McGilvray RW, Eagle RA, Watson NF, Al-Attar A, Ball G, Jafferji I, et al. NKG2D ligand expression in human colorectal cancer reveals associations with prognosis and evidence for immunoediting. Clin Cancer Res. (2009) 15:6993-7002. doi: 10.1158/1078-0432.CCR-09-0991

9. Vitale M, Cantoni C, Pietra G, Mingari MC, Moretta L. Effect of tumor cells and tumor microenvironment on NK-cell function. Eur J Immunol. (2014) 44:1582-92. doi: 10.1002/eji.201344272

10. Mushtaq MU, Papadas A, Pagenkopf A, Flietner E, Morrow Z, Chaudhary SG, et al. Tumor matrix remodeling and novel immunotherapies: the promise of matrix-derived immune biomarkers. I ImmunoTher Cancer. (2018) 6:65. doi: 10.1186/s40425-018-0376-0

11. Mao Y, Sarhan D, Steven A, Seliger B, Kiessling R, Lundqvist A. Inhibition of tumor-derived prostaglandin-E2 blocks the induction of myeloid-derived suppressor cells and recovers natural killer cell activity. Clin Cancer Res. (2014) 20:4096-106. doi: 10.1158/1078-0432.CCR-14-0635

12. Cekic C, Day YJ, Sag D, Linden J. Myeloid expression of adenosine A2A receptor suppresses $\mathrm{T}$ and $\mathrm{NK}$ cell responses in the solid tumor microenvironment. Cancer Res. (2014) 74:7250-9. doi: 10.1158/0008-5472.CAN-13-3583

13. Della Chiesa M, Carlomagno S, Frumento G, Balsamo M, Cantoni $\mathrm{C}$, Conte $\mathrm{R}$, et al. The tryptophan catabolite L-kynurenine inhibits the surface expression of NKp46- and NKG2Dactivating receptors and regulates NK-cell function. Blood. (2006) 108:4118-25. doi: 10.1182/blood-2006-03-006700

14. Kopp HG, Placke T, Salih HR. Platelet-derived transforming growth factor-beta down-regulates NKG2D thereby inhibiting natural killer cell antitumor reactivity. Cancer Res. (2009) 69:7775-83. doi: 10.1158/0008-5472.CAN-09-2123

15. Nieswandt B, Hafner M, Echtenacher B, Mannel DN. Lysis of tumor cells by natural killer cells in mice is impeded by platelets. Cancer Res. (1999) 59:1295-300.

16. Palumbo JS, Talmage KE, Massari JV, La Jeunesse CM, Flick MJ, Kombrinck KW, et al. Platelets and fibrin(ogen) increase metastatic potential by impeding natural killer cell-mediated elimination of tumor cells. Blood. (2005) 105:178-85. doi: 10.1182/blood-2004-06-2272

17. Morvan MG, Lanier LL. NK cells and cancer: you can teach innate cells new tricks. Nat Rev Cancer. (2016) 16:7-19. doi: 10.1038/nrc.2015.5

18. Ortaldo JR, Herberman RB. Heterogeneity of natural killer cells. Ann Rev Immunol. (1984) 2:359-94. doi: 10.1146/annurev.iy.02.040184.002043

19. Vivier E, Tomasello E, Baratin M, Walzer T, Ugolini S. Functions of natural killer cells. Nat Immunol. (2008) 9:503. doi: 10.1038/ni1582

20. Freud AG, Yu J, Caligiuri MA. Human natural killer cell development in secondary lymphoid tissues. Semi Immunol. (2014) 26:132-7. doi: 10.1016/j.smim.2014.02.008

21. Campbell KS, Hasegawa J. Natural killer cell biology: an update and future directions. J Allergy Clin Immunol. (2013) 132:536-44. doi: 10.1016/j.jaci.2013.07.006
22. Campbell KS, Purdy AK. Structure/function of human killer cell immunoglobulin-like receptors: lessons from polymorphisms, evolution, crystal structures and mutations. Immunology. (2011) 132:315-25. doi: 10.1111/j.1365-2567.2010.03398.x

23. Lazetic S, Chang C, Houchins JP, Lanier LL, Phillips JH. Human natural killer cell receptors involved in MHC class I recognition are disulfide-linked heterodimers of CD94 and NKG2 subunits. J Immunol. (1996) 157:4741-5.

24. Schenkel AR, Kingry LC, Slayden RA. The ly49 gene family. a brief guide to the nomenclature, genetics, and role in intracellular infection. Front Immunol. (2013) 4:90. doi: 10.3389/fimmu.2013.00090

25. Martinet L, Smyth MJ. Balancing natural killer cell activation through paired receptors. Nat Rev Immunol. (2015) 15:243-54. doi: 10.1038/nri3799

26. Voskoboinik I, Smyth MJ, Trapani JA. Perforin-mediated target-cell death and immune homeostasis. Nat Rev Immunol. (2006) 6:94052. doi: 10.1038/nri1983

27. Screpanti V, Wallin RP, Grandien A, Ljunggren HG. Impact of FASL-induced apoptosis in the elimination of tumor cells by NK cells. Mol Immunol. (2005) 42:495-9. doi: 10.1016/j.molimm.2004.07.033

28. Fauriat C, Long EO, Ljunggren HG, Bryceson YT. Regulation of human NKcell cytokine and chemokine production by target cell recognition. Blood. (2010) 115:2167-76. doi: 10.1182/blood-2009-08-238469

29. Sanmamed MF, Chen L. A Paradigm shift in cancer immunotherapy: from enhancement to normalization. Cell. (2018) 175:31326. doi: 10.1016/j.cell.2018.09.035

30. Floros T, Tarhini AA. Anticancer cytokines: biology and clinical effects of interferon-alpha2, interleukin (IL)-2, IL-15, IL-21, and IL-12. Semi Oncol. (2015) 42:539-48. doi: 10.1053/j.seminoncol.2015.05.015

31. Srivastava S, Pelloso D, Feng H, Voiles L, Lewis D, Haskova Z, et al. Effects of interleukin-18 on natural killer cells: costimulation of activation through Fc receptors for immunoglobulin. Cancer Immunol Immunother. (2013) 62:1073-82. doi: 10.1007/s00262-013-1403-0

32. Fang F, Xiao W, Tian Z. NK cell-based immunotherapy for cancer. Semi Immunol. (2017) 31:37-54. doi: 10.1016/j.smim.2017.07.009

33. Lin JX, Leonard WJ. The common cytokine receptor gamma chain family of cytokines. Cold Spring Harbor Perspect Biol. (2018) 10:a028449. doi: 10.1101/cshperspect.a028449

34. Davis ZB, Felices M, Verneris MR, Miller JS. Natural killer cell adoptive transfer therapy: exploiting the first line of defense against cancer. Cancer J. (2015) 21:486-91. doi: 10.1097/PPO.0000000000000156

35. Ito S, Bollard CM, Carlsten M, Melenhorst JJ, Biancotto A, Wang E, et al. Ultra-low dose interleukin-2 promotes immune-modulating function of regulatory $\mathrm{T}$ cells and natural killer cells in healthy volunteers. Mol Ther. (2014) 22:1388-95. doi: 10.1038/mt.2014.50

36. Levin AM, Bates DL, Ring AM, Krieg C, Lin JT, Su L, et al. Exploiting a natural conformational switch to engineer an interleukin-2 'superkine'. Nature. (2012) 484:529. doi: 10.1038/nature10975

37. Sim GC, Liu C, Wang E, Liu H, Creasy C, Dai Z, et al. IL2 Variant circumvents ICOS+ Regulatory T-cell expansion and promotes NK cell activation. Cancer Immunol Res. (2016) 4:983-94. doi: 10.1158/2326-6066.CIR-15-0195

38. Ghasemi R, Lazear E, Wang X, Arefanian S, Zheleznyak A, Carreno BM, et al. Selective targeting of IL-2 to NKG2D bearing cells for improved immunotherapy. Nat Commun. (2016) 7:12878. doi: 10.1038/ncomms12878

39. Waldmann TA. The biology of interleukin-2 and interleukin-15: implications for cancer therapy and vaccine design. Nat Rev Immunol. (2006) 6:595. doi: 10.1038/nri1901

40. Conlon KC, Lugli E, Welles HC, Rosenberg SA, Fojo AT, Morris JC, et al. Redistribution, hyperproliferation, activation of natural killer cells and CD8 T cells, and cytokine production during first-in-human clinical trial of recombinant human interleukin-15 in patients with cancer. J Clin Oncol. (2015) 33:74-82. doi: 10.1200/JCO.2014.57.3329

41. Miller JS, Morishima C, McNeel DG, Patel MR, Kohrt HEK, Thompson JA, et al. A First-in-Human phase i study of subcutaneous outpatient recombinant human IL15 (rhIL15) in adults with advanced solid tumors. Clin Cancer Res. (2018) 24:1525-35. doi: 10.1158/1078-0432.CCR-1 7-2451

42. Wong HC, Jeng EK, Rhode PR. The IL-15-based superagonist ALT-803 promotes the antigen-independent conversion of memory CD8 $(+) \mathrm{T}$ cells 
into innate-like effector cells with antitumor activity. Oncoimmunology. (2013) 2: e26442. doi: 10.4161/onci.26442

43. Han KP, Zhu X, Liu B, Jeng E, Kong L, Yovandich JL, et al. IL15:IL-15 receptor alpha superagonist complex: high-level co-expression in recombinant mammalian cells, purification and characterization. Cytokine. (2011) 56:804-10. doi: 10.1016/j.cyto.2011.09.028

44. Romee R, Cooley S, Berrien-Elliott MM. First-in-human phase 1 clinical study of the IL-15 superagonist complex ALT-803 to treat relapse after transplantation. Blood. (2018) 131:251527. doi: 10.1182/blood-2017-12-823757

45. Wrangle JM, Velcheti V, Patel MR, Garrett-Mayer E, Hill EG, Ravenel JG, et al. ALT-803, an IL-15 superagonist, in combination with nivolumab in patients with metastatic non-small cell lung cancer: a non-randomised, open-label, phase $1 \mathrm{~b}$ trial. Lancet Oncol. (2018) 19:694-704. doi: 10.1016/S1470-2045(18)30148-7

46. Soiffer RJ. Can IL-15 superagonist ALTer GVL? Blood. (2018) 131:25112. doi: 10.1182/blood-2018-04-840835

47. Rosser CJ, Nix J, Ferguson L, Wong H. Phase IB trial of ALT-803, an IL-15 superagonist, plus bacillus calmette guerin (BCG) for the treatment of BCGnaive patients with non-muscle-invasive bladder cancer (NMIBC). J Urol. (2017) 197:e175. doi: 10.1016/j.juro.2017.02.497

48. Carotta S. Targeting NK cells for anticancer immunotherapy: clinical and preclinical approaches. Front Immunol. (2016) 7:152. doi: 10.3389/fimmu.2016.00152

49. Varchetta S, Gibelli N, Oliviero B, Nardini E, Gennari R, Gatti $\mathrm{G}$, et al. Elements related to heterogeneity of antibody-dependent cell cytotoxicity in patients under trastuzumab therapy for primary operable breast cancer overexpressing Her2. Cancer Res. (2007) 67:119919. doi: 10.1158/0008-5472.CAN-07-2068

50. Bruhns P, Iannascoli B, England P, Mancardi DA, Fernandez N, Jorieux $\mathrm{S}$, et al. Specificity and affinity of human Fcgamma receptors and their polymorphic variants for human IgG subclasses. Blood. (2009) 113:371625. doi: 10.1182/blood-2008-09-179754

51. Nechansky A, Schuster M, Jost W, Siegl P, Wiederkum S, Gorr G, et al. Compensation of endogenous IgG mediated inhibition of antibody-dependent cellular cytotoxicity by glycoengineering of therapeutic antibodies. Mol Immunol. (2007) 44:1815-7. doi: 10.1016/j.molimm.2006.08.013

52. Iida S, Misaka H, Inoue M, Shibata M, Nakano R, Yamane-Ohnuki N, et al. Nonfucosylated therapeutic IgG1 antibody can evade the inhibitory effect of serum immunoglobulin $\mathrm{G}$ on antibody-dependent cellular cytotoxicity through its high binding to FcgammaRIIIa. Clin Cancer Res. (2006) 12:287987. doi: 10.1158/1078-0432.CCR-05-2619

53. Koerner SP, Andre MC, Leibold JS, Kousis PC, Kubler A, Pal M, et al. An Fc-optimized CD133 antibody for induction of NK cell reactivity against myeloid leukemia. Leukemia. (2017) 31:459-69. doi: 10.1038/leu.2016.194

54. Kim YM, Park JS, Kim SK, Jung KM, Hwang YS, Han M, et al. The transgenic chicken derived anti-CD20 monoclonal antibodies exhibits greater anti-cancer therapeutic potential with enhanced $\mathrm{Fc}$ effector functions. Biomaterials. (2018) 167:58-68. doi: 10.1016/j.biomaterials.2018.03.021

55. Ferrari de Andrade L, Tay RE. Antibody-mediated inhibition of MICA and MICB shedding promotes NK cell-driven tumor immunity. Science. (2018) 359:1537-42. doi: 10.1126/science.aao0505

56. Albertini MR, Yang RK, Ranheim EA, Hank JA, Zuleger CL, Weber S, et al. Pilot trial of the hu14.18-IL2 immunocytokine in patients with completely resectable recurrent stage III or stage IV melanoma. Cancer Immunol Immunother. (2018) 67:1647-58. doi: 10.1007/s00262-018-2223-z

57. Kellner C, Bruenke J, Horner H, Schubert J, Schwenkert M, Mentz $\mathrm{K}$, et al. Heterodimeric bispecific antibody-derivatives against CD19 and CD16 induce effective antibody-dependent cellular cytotoxicity against B-lymphoid tumor cells. Cancer Lett. (2011) 303:128-39. doi: 10.1016/j.canlet.2011.01.020

58. Bruenke J, Barbin K, Kunert S, Lang P, Pfeiffer M, Stieglmaier K, et al. Effective lysis of lymphoma cells with a stabilised bispecific single-chain $\mathrm{Fv}$ antibody against CD19 and FcgammaRIII (CD16). Br J Haematol. (2005) 130:218-28. doi: 10.1111/j.1365-2141.2005.05414.x

59. Gleason MK, Verneris MR, Todhunter DA, Zhang B, McCullar V, Zhou SX, et al. Bispecific and trispecific killer cell engagers directly activate human NK cells through CD16 signaling and induce cytotoxicity and cytokine production. Mol Cancer Therap. (2012) 11:2674-84. doi: 10.1158/1535-7163.MCT-12-0692

60. Wiernik A, Foley B, Zhang B, Verneris MR, Warlick E, Gleason MK, et al. Targeting natural killer cells to acute myeloid leukemia in vitro with a CD16 x 33 bispecific killer cell engager and ADAM17 inhibition. Clin Cancer Res. (2013) 19:3844-55. doi: 10.1158/1078-0432.CCR-13-0505

61. Chan WK, Kang S, Youssef Y, Glankler EN, Barrett ER, Carter AM, et al. A CS1-NKG2D Bispecific antibody collectively activates cytolytic immune cells against multiple myeloma. Cancer Immunol Res. (2018) 6:77687. doi: 10.1158/2326-6066.CIR-17-0649

62. Rothe A, Sasse S, Topp MS, Eichenauer DA, Hummel H, Reiners KS, et al. A phase 1 study of the bispecific anti-CD30/CD16A antibody construct AFM13 in patients with relapsed or refractory Hodgkin lymphoma. Blood. (2015) 125:4024-31. doi: 10.1182/blood-2014-12-614636

63. Wu J, Fu J, Zhang M, Liu D. AFM13: a first-in-class tetravalent bispecific antiCD30/CD16A antibody for NK cell-mediated immunotherapy. J Hematol Oncol. (2015) 8:96. doi: 10.1186/s13045-015-0188-3

64. Pahl JHW, Koch J, Gotz JJ, Arnold A, Reusch U, Gantke T, et al. CD16A Activation of NK Cells Promotes NK cell proliferation and memorylike cytotoxicity against cancer cells. Cancer Immunol Res. (2018) 6:51727. doi: 10.1158/2326-6066.CIR-17-0550

65. Tay SS, Carol H, Biro M. TriKEs and BiKEs join CARs on the cancer immunotherapy highway. Human Vacci Immunotherap. (2016) 12:27906. doi: $10.1080 / 21645515.2016 .1198455$

66. Vallera DA, Felices M, McElmurry R, McCullar V, Zhou X, Schmohl $\mathrm{JU}$, et al. IL15 trispecific killer engagers (TriKE) make natural killer cells specific to $\mathrm{CD} 33+$ targets while also inducing persistence, in vivo expansion, and enhanced function. Clin Cancer Res. (2016) 22:344050. doi: 10.1158/1078-0432.CCR-15-2710

67. Schmohl JU, Felices M, Taras E, Miller JS, Vallera DA. Enhanced ADCC and NK Cell activation of an anticarcinoma bispecific antibody by genetic insertion of a modified IL-15 cross-linker. Mol Ther. (2016) 24:131222. doi: $10.1038 / \mathrm{mt} .2016 .88$

68. Davis ZB, Vallera DA, Miller JS, Felices M. Natural killer cells unleashed: checkpoint receptor blockade and BiKE/TriKE utilization in NK-mediated anti-tumor immunotherapy. Semi Immunol. (2017) 31:64-75. doi: 10.1016/j.smim.2017.07.011

69. Talmadge JE. Genetically engineered multivalent proteins for targeted immunotherapy. Clin Cancer Res. (2016) 22:341921. doi: 10.1158/1078-0432.CCR-16-0246

70. Tzeng A, Kwan BH, Opel CF, Navaratna T, Wittrup KD. Antigen specificity can be irrelevant to immunocytokine efficacy and biodistribution. Proc Natl Acad Sci U.S.A. (2015) 112:3320-5. doi: 10.1073/pnas.1416159112

71. Thakur A, Lum LG. "NextGen" biologics: bispecific antibodies and emerging clinical results. Exp Opin Biol Ther. (2016) 16:675-88. doi: 10.1517/14712598.2016.1150996

72. Benson DM Jr., Bakan CE, Zhang S, Collins SM, Liang J, Srivastava S, et al. IPH2101, a novel anti-inhibitory KIR antibody, and lenalidomide combine to enhance the natural killer cell versus multiple myeloma effect. Blood. (2011) 118:6387-91. doi: 10.1182/blood-2011-06-360255

73. Romagne F, Andre P, Spee P, Zahn S, Anfossi N, Gauthier L, et al. Preclinical characterization of 1-7F9, a novel human anti-KIR receptor therapeutic antibody that augments natural killer-mediated killing of tumor cells. Blood. (2009) 114:2667-77. doi: 10.1182/blood-2009-02-206532

74. Benson DM Jr., Hofmeister CC, Padmanabhan S, Suvannasankha A, Jagannath S, Abonour R, et al. A phase 1 trial of the anti-KIR antibody IPH2101 in patients with relapsed/refractory multiple myeloma. Blood. (2012) 120:4324-33. doi: 10.1182/blood-2012-06-438028

75. Vey N, Bourhis JH, Boissel N, Bordessoule D, Prebet T, Charbonnier A, et al. A phase 1 trial of the anti-inhibitory KIR mAb IPH2101 for AML in complete remission. Blood. (2012) 120:4317-23. doi: 10.1182/blood-2012-06-437558

76. Korde N, Carlsten M, Lee MJ, Minter A, Tan E, Kwok M, et al. A phase II trial of pan-KIR2D blockade with IPH2101 in smoldering multiple myeloma. Haematologica. (2014) 99:e81-3. doi: 10.3324/haematol.2013.103085

77. Carlsten M, Korde N, Kotecha R, Reger R, Bor S, Kazandjian $\mathrm{D}$, et al. Checkpoint Inhibition of KIR2D with the monoclonal antibody IPH2101 induces contraction and hyporesponsiveness 
of NK cells in patients with myeloma. Clin Cancer Res. (2016) 22:5211-22. doi: 10.1158/1078-0432.CCR-16-1108

78. Vey N, Karlin L, Sadot-Lebouvier S, Broussais F, Berton-Rigaud D, Rey J, et al. A phase 1 study of lirilumab (antibody against killer immunoglobulin-like receptor antibody KIR2D; IPH2102) in patients with solid tumors and hematologic malignancies. Oncotarget. 9:1767588. doi: 10.18632 /oncotarget. 24832

79. Ruggeri L, Urbani E, André P, Mancusi A, Tosti A, Topini F, et al. Effects of anti-NKG2A antibody administration on leukemia and normal hematopoietic cells. Haematologica. (2016) 101:626-33. doi: 10.3324/haematol.2015.135301

80. Ohaegbulam KC, Assal A, Lazar-Molnar E, Yao Y, Zang X. Human cancer immunotherapy with antibodies to the PD-1 and PD-L1 pathway. Trends Mol Med. (2015) 21:24-33. doi: 10.1016/j.molmed.2014.10.009

81. Zhang Q, Bi J, Zheng X, Chen Y, Wang H, Wu W, et al. Blockade of the checkpoint receptor TIGIT prevents NK cell exhaustion and elicits potent anti-tumor immunity. Nat Immunol. (2018) 19:723-32. doi: 10.1038/s41590-018-0132-0

82. Kim N, Kim HS. Targeting checkpoint receptors and molecules for therapeutic modulation of natural killer cells. Front Immunol. (2018) 9:2041. doi: 10.3389/fimmu.2018.02041

83. Burns LJ, Weisdorf DJ, DeFor TE, Vesole DH, Repka TL, Blazar BR, et al. IL-2-based immunotherapy after autologous transplantation for lymphoma and breast cancer induces immune activation and cytokine release: a phase I/II trial. Bone Marrow Transpl. (2003) 32:177-86. doi: 10.1038/sj.bmt. 1704086

84. Krause SW, Gastpar R, Andreesen R, Gross C, Ullrich H, Thonigs G, et al. Treatment of colon and lung cancer patients with ex vivo heat shock protein 70-peptide-activated, autologous natural killer cells: a clinical phase i trial. Clin Cancer Res. (2004) 10:3699-707. doi: 10.1158/1078-0432.CCR03-0683

85. Parkhurst MR, Riley JP, Dudley ME, Rosenberg SA. Adoptive transfer of autologous natural killer cells leads to high levels of circulating natural killer cells but does not mediate tumor regression. Clin Cancer Res. (2011) 17:6287-97. doi: 10.1158/1078-0432.CCR11-1347

86. Geller MA, Cooley S, Judson PL, Ghebre R, Carson LF, Argenta PA, et al. A phase II study of allogeneic natural killer cell therapy to treat patients with recurrent ovarian and breast cancer. Cytotherapy. (2011) 13:98107. doi: $10.3109 / 14653249.2010 .515582$

87. Ruggeri L, Capanni M, Urbani E, Perruccio K, Shlomchik WD, Tosti A, et al. Effectiveness of donor natural killer cell alloreactivity in mismatched hematopoietic transplants. Science. (2002) 295:2097-100. doi: 10.1126/science.1068440

88. Miller JS, Soignier Y, Panoskaltsis-Mortari A, McNearney SA, Yun GH, Fautsch SK, et al. Successful adoptive transfer and in vivo expansion of human haploidentical NK cells in patients with cancer. Blood. (2005) 105:3051-7. doi: 10.1182/blood-2004-07-2974

89. Abel AM, Yang C, Thakar MS, Malarkannan S. Natural killer cells: development, maturation, and clinical utilization. Front Immunol. (2018) 9:01869. doi: 10.3389/fimmu.2018.01869

90. Cheng M, Chen Y, Xiao W, Sun R, Tian Z. NK cell-based immunotherapy for malignant diseases. Cell Mol Immunol. (2013) 10:230-52. doi: $10.1038 / \mathrm{cmi} .2013 .10$

91. Leung W. Infusions of allogeneic natural killer cells as cancer therapy. Clin Cancer Res. (2014) 20:3390-400. doi: 10.1158/1078-0432.CCR-13-1766

92. Klingemann HG, Martinson J. Ex vivo expansion of natural killer cells for clinical applications. Cytotherapy. (2004) 6:1522. doi: 10.1080/14653240310004548

93. Klingemann H, Boissel L, Toneguzzo F. Natural killer cells for immunotherapy - advantages of the NK-92 cell line over blood NK cells. Front Immunol. (2016) 7:91. doi: 10.3389/fimmu.2016. 00091

94. Tonn T, Schwabe D, Klingemann HG, Becker S, Esser R, Koehl U, et al. Treatment of patients with advanced cancer with the natural killer cell line NK-92. Cytotherapy. (2013) 15:1563-70. doi: 10.1016/j.jcyt.2013. 06.017
95. Suck G, Odendahl M, Nowakowska P, Seidl C, Wels WS, Klingemann HG, et al. NK-92: an 'off-the-shelf therapeutic' for adoptive natural killer cell-based cancer immunotherapy. Cancer Immunol Immunother. (2016) 65:485-92. doi: 10.1007/s00262-015$1761-\mathrm{x}$

96. Arai S, Meagher R, Swearingen M, Myint H, Rich E, Martinson J, et al. Infusion of the allogeneic cell line NK-92 in patients with advanced renal cell cancer or melanoma: a phase I trial. Cytotherapy. (2008) 10:62532. doi: $10.1080 / 14653240802301872$

97. Boyiadzis M, Agha M, Redner RL, Sehgal A, Im A, Hou JZ, et al. Phase 1 clinical trial of adoptive immunotherapy using "off-the-shelf" activated natural killer cells in patients with refractory and relapsed acute myeloid leukemia. Cytotherapy. (2017) 19:1225-32. doi: 10.1016/j.jcyt.2017. 07.008

98. Jochems C, Hodge JW, Fantini M, Fujii R, Morillon YM II, Greiner JW, et al. An NK cell line (haNK) expressing high levels of granzyme and engineered to express the high affinity CD16 allele. Oncotarget. (2016) 7:86359-73. doi: 10.18632/oncotarget.13411

99. Hermanson DL, Kaufman DS. Utilizing chimeric antigen receptors to direct natural killer cell activity. Front Immunol. (2015) 6:195. doi: 10.3389/fimmu.2015.00195

100. Zhang C, Oberoi P, Oelsner S, Waldmann A, Lindner A, Tonn T, et al. Chimeric antigen receptor-engineered NK-92 Cells: an off-theshelf cellular therapeutic for targeted elimination of cancer cells and induction of protective antitumor immunity. Front Immunol. (2017) 8:533. doi: $10.3389 /$ fimmu.2017.00533

101. Eguizabal C, Zenarruzabeitia O, Monge J, Santos S, Vesga MA, Maruri N, et al. Natural killer cells for cancer immunotherapy: pluripotent stem cellsderived NK cells as an immunotherapeutic perspective. Front Immunol. (2014) 5:439. doi: 10.3389/fimmu.2014.00439

102. Ni F, Sun R, Fu B, Wang F, Guo C, Tian Z, et al. IGF-1 promotes the development and cytotoxic activity of human NK cells. Nat Commun. (2013) 4:1479. doi: $10.1038 /$ ncomms 2484

103. Woll PS, Grzywacz B, Tian X, Marcus RK, Knorr DA, Verneris MR, et al. Human embryonic stem cells differentiate into a homogeneous population of natural killer cells with potent in vivo antitumor activity. Blood. (2009) 113:6094-101. doi: 10.1182/blood-2008-06-165225

104. Knorr DA, Ni Z, Hermanson D, Hexum MK, Bendzick L, Cooper LJN, et al. Clinical-Scale derivation of natural killer cells from human pluripotent stem cells for cancer therapy. Stem Cells Transl Med. (2013) 2:27483. doi: 10.5966/sctm.2012-0084

105. Hermanson DL, Bendzick L, Pribyl L, McCullar V, Vogel RI, Miller JS, et al. Induced pluripotent stem cell-derived natural killer cells for treatment of ovarian cancer. Stem Cells. (2016) 34:93-101. doi: 10.1002/ stem.2230

106. Woll PS, Martin CH, Miller JS, Kaufman DS. Human embryonic stem cell-derived NK cells acquire functional receptors and cytolytic activity. J Immunol. (2005) 175:5095-103. doi: 10.4049/jimmunol.175. 8.5095

107. Nham T, Poznanski SM, Fan IY, Vahedi F, Shenouda MM, Lee $\mathrm{AJ}$, et al. Ex Vivo-expanded natural killer cells derived from longterm cryopreserved cord blood are cytotoxic against primary breast cancer cells. J Immunother. (2018) 41:64-72. doi: 10.1097/CJI.000000000 0000192

108. Dolstra H, Roeven MWH, Spanholtz J, Hangalapura BN, Tordoir M, Maas F, et al. Successful transfer of umbilical cord blood CD34(+) hematopoietic stem and progenitor-derived NK cells in older acute myeloid leukemia patients. Clin Cancer Res. (2017) 23:4107-18. doi: 10.1158/1078-0432.CCR16-2981

109. Chiossone L, Vienne M, Kerdiles YM, Vivier E. Natural killer cell immunotherapies against cancer: checkpoint inhibitors and more. Semi Immunol. (2017) 31:55-63. doi: 10.1016/j.smim.2017.08.003

110. Cifaldi L, Locatelli F, Marasco E, Moretta L, Pistoia V. Boosting natural killer cell-based immunotherapy with anticancer drugs: a perspective. Trends $\mathrm{Mol}$ Med. (2017) 23:1156-75. doi: 10.1016/j.molmed.2017.10.002

111. Xu Y, Sun J, Sheard MA, Tran HC, Wan Z, Liu WY, et al. Lenalidomide overcomes suppression of human natural killer cell anti-tumor functions 
by neuroblastoma microenvironment-associated IL- 6 and TGFbeta1. Cancer Immunol. Immunother. (2013) 62:1637-48. doi: 10.1007/s00262-013-1466-y

112. Lagrue K, Carisey A, Morgan DJ, Chopra R, Davis DM. Lenalidomide augments actin remodeling and lowers NK-cell activation thresholds. Blood. (2015) 126:50-60. doi: 10.1182/blood-2015-01-625004

113. Daher M, Rezvani K. Next generation natural killer cells for cancer immunotherapy: the promise of genetic engineering. Curr Opin Immunol. (2018) 51:146-53. doi: 10.1016/j.coi.2018.03.013

114. Oberschmidt O, Kloess S, Koehl U. Redirected primary human chimeric antigen receptor natural killer cells as an "Off-the-Shelf Immunotherapy" for improvement in cancer treatment. Front Immunol. (2017) 8:654. doi: 10.3389/fimmu.2017.00654

115. Srivastava $\mathrm{S}$, Riddell SR. Chimeric antigen receptor $\mathrm{t}$ cell therapy: challenges to bench-to-bedside efficacy. J Immunol. (2018) 200:45968. doi: 10.4049/jimmunol.1701155

116. Tran AC, Zhang D, Byrn R, Roberts MR. Chimeric zeta-receptors direct human natural killer (NK) effector function to permit killing of NK-resistant tumor cells and HIV-infected T lymphocytes. J Immunol. (1995) 155:1000-9.

117. Uherek C, Tonn T, Uherek B, Becker S, Schnierle B, Klingemann H-G, et al. Retargeting of natural killer-cell cytolytic activity to ErbB2-expressing cancer cells results in efficient and selective tumor cell destruction. Blood. (2002) 100:1265-73. Available online at: http://www.bloodjournal.org/content/100/4/1265

118. Imai C. Genetic modification of primary natural killer cells overcomes inhibitory signals and induces specific killing of leukemic cells. Blood. (2005) 106:376-83. doi: 10.1182/blood-2004-12-4797

119. Klingemann H. Are natural killer cells superior CAR drivers? Oncoimmunology. (2014) 3:e28147. doi: 10.4161/onci.28147

120. Natural killer cells for cancer immunotherapy: a new CAR is catching up. EBioMedicine. (2019) 39:1-2. doi: 10.1016/j.ebiom.2019.01.018

121. Kruschinski A, Moosmann A, Poschke I, Norell H, Chmielewski M, Seliger $B$, et al. Engineering antigen-specific primary human NK cells against HER-2 positive carcinomas. Proc Natl Acad Sci USA. (2008) 105:174816. doi: $10.1073 /$ pnas. 0804788105

122. Oelsner S, Friede ME, Zhang C, Wagner J, Badura S, Bader P, et al. Continuously expanding CAR NK-92 cells display selective cytotoxicity against B-cell leukemia and lymphoma. Cytotherapy. (2017) 19:23549. doi: 10.1016/j.jcyt.2016.10.009

123. Altvater B, Landmeier S, Pscherer S, Temme J, Schweer K, Kailayangiri S, et al. 2B4 (CD244) signaling by recombinant antigenspecific chimeric receptors costimulates natural killer cell activation to leukemia and neuroblastoma cells. Clin Cancer Res. (2009) 15:4857-66. doi: 10.1158/1078-0432.CCR-08-2810

124. Li Y, Hermanson DL, Moriarity BS, Kaufman DS. Human iPSCDerived natural killer cells engineered with chimeric antigen receptors enhance anti-tumor activity. Cell Stem Cell. (2018) 23:181-92 e5. doi: 10.1016/j.stem.2018.06.002

125. Guven H, Konstantinidis KV, Alici E, Aints A, Abedi-Valugerdi M, Christensson B, et al. Efficient gene transfer into primary human natural killer cells by retroviral transduction. Experi Hematol. (2005) 33:13208. doi: 10.1016/j.exphem.2005.07.006

126. Lowe E, Truscott LC, De Oliveira SN. In vitro generation of human NK cells expressing chimeric antigen receptor through differentiation of genemodified hematopoietic stem cells. Methods Mol Biol. (2016) 1441:24151. doi: 10.1007/978-1-4939-3684-7_20

127. Davila ML, Kloss CC, Gunset G, Sadelain M. CD19 CAR-targeted T cells induce long-term remission and B Cell Aplasia in an immunocompetent mouse model of B cell acute lymphoblastic leukemia. PLoS ONE. (2013) 8:e61338. doi: 10.1371/journal.pone.0061338

128. Genssler S, Burger MC, Zhang C, Oelsner S, Mildenberger I, Wagner M, et al. Dual targeting of glioblastoma with chimeric antigen receptor-engineered natural killer cells overcomes heterogeneity of target antigen expression and enhances antitumor activity and survival. Oncoimmunology. (2016) 5:e1119354. doi: 10.1080/2162402X.2015.1119354

129. Hegde M, Mukherjee M, Grada Z, Pignata A, Landi D, Navai SA, et al. Tandem CAR $\mathrm{T}$ cells targeting HER2 and IL13Ralpha2 mitigate tumor antigen escape. J Clin Invest. (2016) 126:3036-52. doi: 10.1172/JCI 83416
130. Zah E, Lin MY, Silva-Benedict A, Jensen MC, Chen YY. T Cells Expressing CD19/CD20 bispecific chimeric antigen receptors prevent antigen escape by malignant B cells. Cancer Immunol Res. (2016) 4:498508. doi: 10.1158/2326-6066.CIR-15-0231

131. Di Stasi A, Tey SK, Dotti G, Fujita Y, Kennedy-Nasser A, Martinez C, et al. Inducible apoptosis as a safety switch for adoptive cell therapy. N Engl J Med. (2011) 365:1673-83. doi: 10.1056/NEJMoa1106152

132. Wu CY, Roybal KT, Puchner EM, Onuffer J, Lim WA. Remote control of therapeutic $\mathrm{T}$ cells through a small molecule-gated chimeric receptor. Science. (2015) 350: aab4077. doi: 10.1126/science.aab4077

133. Shah NN, Baird K, Delbrook CP, Fleisher TA, Kohler ME, Rampertaap S, et al. Acute GVHD in patients receiving IL-15/4-1BBL activated NK cells following T-cell-depleted stem cell transplantation. Blood. (2015) 125:78492. doi: 10.1182/blood-2014-07-592881

134. Raimondo F, Morosi L, Chinello C, Magni F, Pitto M. Advances in membranous vesicle and exosome proteomics improving biological understanding and biomarker discovery. Proteomics. (2011) 11:70920. doi: $10.1002 /$ pmic. 201000422

135. Schorey JS, Bhatnagar S. Exosome function: from tumor immunology to pathogen biology. Traffic. (2008) 9:87181. doi: 10.1111/j.1600-0854.2008.00734.x

136. Thery C, Zitvogel L, Amigorena S. Exosomes: composition, biogenesis and function. Nat Rev Immunol. (2002) 2:569-79. doi: 10.1038/nri855

137. Yanez-Mo M, Siljander PR, Andreu Z, Zavec AB, Borras FE, Buzas EI, et al. Biological properties of extracellular vesicles and their physiological functions. J Extracell Vesicles. (2015) 4:27066. doi: 10.3402/jev.v4.27066

138. Armstrong JP, Holme MN, Stevens MM. Re-Engineering extracellular vesicles as smart nanoscale therapeutics. ACS Nano. (2017) 11:6983. doi: 10.1021 /acsnano.6b07607

139. Gyorgy B, Hung ME, Breakefield XO, Leonard JN. Therapeutic applications of extracellular vesicles: clinical promise and open questions. Ann Rev Pharmacol Toxicol. (2015) 55:43964. doi: 10.1146/annurev-pharmtox-010814-124630

140. Fischer B, Muller B, Fischer KG, Baur N, Kreutz W. Acidic pH inhibits non-MHC-restricted killer cell functions. Clin Immunol. (2000) 96:25263. doi: 10.1006/clim.2000.4904

141. Helmlinger G, Yuan F, Dellian M, Jain RK. Interstitial pH and pO2 gradients in solid tumors in vivo: high-resolution measurements reveal a lack of correlation. Nat Med. (1997) 3:177-82. doi: 10.1038/nm0297-177

142. Parolini I, Federici C, Raggi C, Lugini L, Palleschi S, De Milito A, et al. Microenvironmental $\mathrm{pH}$ is a key factor for exosome traffic in tumor cells. J Biol Chem. (2009) 284:34211-22. doi: 10.1074/jbc.M109.041152

143. Alvarez-Erviti L, Seow Y, Yin H, Betts C, Lakhal S, Wood MJ. Delivery of siRNA to the mouse brain by systemic injection of targeted exosomes. Nat Biotechnol. (2011) 29:341-5. doi: 10.1038/nbt.1807

144. Wood MJ, O'Loughlin AJ, Samira L. Exosomes and the blood-brain barrier: implications for neurological diseases. Therap Delivery. (2011) 2:10959. doi: $10.4155 /$ tde. 11.83

145. Yang T, Martin P, Fogarty B, Brown A, Schurman K, Phipps R, et al. Exosome delivered anticancer drugs across the blood-brain barrier for brain cancer therapy in Danio rerio. Pharmaceut Res. (2015) 32:200314. doi: 10.1007/s11095-014-1593-y

146. Jong AY, Wu CH, Li J, Sun J, Fabbri M, Wayne AS, et al. Largescale isolation and cytotoxicity of extracellular vesicles derived from activated human natural killer cells. J Extracell Vesicles. (2017) 6:1294368. doi: 10.1080/20013078.2017.1294368

147. Lugini L, Cecchetti S, Huber V, Luciani F, Macchia G, Spadaro F, et al. Immune surveillance properties of human NK cell-derived exosomes. $J$ Immunol. (2012) 189:2833-42. doi: 10.4049/jimmunol.1101988

148. Zhu L, Kalimuthu S, Gangadaran P, Oh JM, Lee HW, Baek SH, et al. Exosomes derived from natural killer cells exert therapeutic effect in melanoma. Theranostics. (2017) 7:2732-45. doi: 10.7150/thno.18752

149. Zhu L, Oh JM, Gangadaran P, Kalimuthu S, Baek SH, Jeong SY, et al. Targeting and therapy of glioblastoma in a mouse model using exosomes derived from natural killer cells. Front Immunol. (2018) 9:824. doi: 10.3389/fimmu.2018.00824

150. Fais S. NK cell-released exosomes: natural nanobullets against tumors. Oncoimmunology. (2013) 2:e22337. doi: 10.4161/onci.22337 
151. Andreola G, Rivoltini L, Castelli C, Huber V, Perego P, Deho P, et al. Induction of lymphocyte apoptosis by tumor cell secretion of FasL-bearing microvesicles. J Experi Med. (2002) 195:1303-16. doi: 10.1084/jem.20011624

152. Huber V, Fais S, Iero M, Lugini L, Canese P, Squarcina P, et al. Human colorectal cancer cells induce T-cell death through release of proapoptotic microvesicles: role in immune escape. Gastroenterology. (2005) 128:1796804. doi: 10.1053/j.gastro.2005.03.045

153. Wen C, Seeger RC, Fabbri M, Wang L, Wayne AS, Jong AY. Biological roles and potential applications of immune cell-derived extracellular vesicles. J Extracell Vesicles. (2017) 6:1400370. doi: 10.1080/20013078.2017.14 00370
Conflict of Interest Statement: The authors declare that the research was conducted in the absence of any commercial or financial relationships that could be construed as a potential conflict of interest.

Copyright (c) $2019 \mathrm{Hu}$, Wang, Huang, Sui and Xu. This is an open-access article distributed under the terms of the Creative Commons Attribution License (CC BY). The use, distribution or reproduction in other forums is permitted, provided the original author(s) and the copyright owner(s) are credited and that the original publication in this journal is cited, in accordance with accepted academic practice. No use, distribution or reproduction is permitted which does not comply with these terms. 